\title{
Intercellular protein-protein interactions at synapses
}

\author{
Xiaofei Yang ${ }^{1 凶}$, Dongmei Hou ${ }^{1,2,3}$, Wei Jiang ${ }^{1,2,3}$, Chen Zhang ${ }^{2,3 凶}$ \\ ${ }^{1}$ Key Laboratory of Cognitive Science, Laboratory of Membrane Ion Channels and Medicine, College of Biomedical \\ Engineering, South-Central University for Nationalities, Wuhan 430074, China \\ 2 State Key Laboratory of Biomembrane and Membrane Biotechnology, College of Life Sciences, Peking University, Beijing \\ 100871, China \\ ${ }^{3}$ PKU-IDG/McGovern Institute for Brain Research, Peking University, Beijing 100871, China \\ $\triangle$ Correspondence: sunlittlefly@gmail.com (X. Yang), ch.zhang@pku.edu.cn (C. Zhang) \\ Received February 16, 2014 Accepted March 23, 2014
}

\begin{abstract}
Chemical synapses are asymmetric intercellular junctions through which neurons send nerve impulses to communicate with other neurons or excitable cells. The appropriate formation of synapses, both spatially and temporally, is essential for brain function and depends on the intercellular protein-protein interactions of cell adhesion molecules (CAMs) at synaptic clefts. The CAM proteins link pre- and post-synaptic sites, and play essential roles in promoting synapse formation and maturation, maintaining synapse number and type, accumulating neurotransmitter receptors and ion channels, controlling neuronal differentiation, and even regulating synaptic plasticity directly. Alteration of the interactions of CAMs leads to structural and functional impairments, which results in many neurological disorders, such as autism, Alzheimer's disease and schizophrenia. Therefore, it is crucial to understand the functions of CAMs during development and in the mature neural system, as well as in the pathogenesis of some neurological disorders. Here, we review the function of the major classes of CAMs, and how dysfunction of CAMs relates to several neurological disorders.
\end{abstract}

KEYWORDS synapse formation, cell-cell adhesion, synaptic plasticity, neurological disorders, protein-protein interaction, cell adhesion molecules

Xiaofei Yang, Dongmei Hou and Wei Jiang have contributed equally to this work.

\section{INTRODUCTION}

The brain is characterized by an enormous degree of complexity and diversity of neural networks, making it one of the most complicated organs. This complexity and diversity come from the vast numbers of neurons, but also from the variety of synapses where neurons pass electrical or chemical signals to other cells. Most of the synapses are small in size (1 $\mu \mathrm{m}$ in diameter), but biochemical studies reveal a high level of the molecular complexity. The postsynaptic proteome of the excitatory synapse of a mammalian brain contains more than 1000 proteins, indicating complicated protein-protein interactions occurring both within and between synapses (Collins et al., 2006; Cheng et al., 2006; Peng et al., 2004; Bayés et al., 2011; Dosemeci et al., 2006; Fernández et al., 2009; Trinidad et al., 2008; Hahn et al., 2009; Satoh et al., 2002).

The synapse is the site where two neurons connect, separated by a narrow $(\sim 20 \mathrm{~nm})$ layer of extracellular space called a synaptic cleft (Akert et al., 1972). The molecular composition of the synaptic cleft still remains largely unclear, but early studies demonstrated the presence of mostly proteins and carbohydrates (GRAY 1959; Pfenninger, 1971; Bloom and Aghajanian, 1966). One of the obvious functions of protein-protein interactions in the clefts is to serve as the "glue" that connects the pre- and post-synaptic neurons. Mounting evidence has confirmed that the adhesiveness of the pre- and post-synaptic compartment (for example, the attachment of pre- and post-synaptic membranes in a synaptosome preparation) is resistant to treatments such as calcium removal, high salt, or even low concentrations of urea treatment (Pfenninger, 1971; Cotman and Taylor, 1972). Further studies have revealed that the CAM-mediated 
intercellular protein-protein interactions at synapses, are involved in the recognition and alignment of pre- and postsynaptic sites, trans-synaptic signaling, and the precise localization of neurotransmitter receptors and releasable vesicles. Alterations in CAMs lead to changes in synaptic morphology and function, and are associated with many neurological disorders including autism, AD and schizophrenia. Several families of CAMs are recognized, including neurexins and neuroligins, leucine-rich repeat transmembrane neuronal proteins (LRRTMs), N-cadherin/ $\beta$-catenin, ephrins and Eph receptors, SynCAM, and integrins. In this review we summarize the known CAMs, their physiology, and their roles in brain pathologies involving protein-protein interactions at synapses.

\section{CAMS: BRIDGES ACROSS THE SYNAPTIC CLEFT}

In the brain, neurons recognize each other and form stable synaptic connections through CAMs. CAMs are proteins locate on the cell surface that serve as "glue" for adhering pre- and post-synaptic terminals together. These proteins are responsible for mechanical stabilization of and organization of synaptic contacts. Typically, they contain three domains: an intracellular domain that interacts with the intracellular scaffold protein, a transmembrane domain, and an extracellular domain that interacts with other CAMs via either trans- or cis-interactions. Most CAMs (e.g., neurexins and neuroligins, SynCAMs, and $\beta 1$ integrin) localize at the center of the synapse (Mortillo et al., 2012); whereas others (e.g., the $\mathrm{N}$-cadherin/ $\beta$-catenin system) are found at the outer rims of pre-synaptic active zones and post-synaptic regions (Uchida et al., 1996).

The CAMs play a crucial role in determining synapse specificity by mediating the initial target recognition between pre- and post-synaptic neurons during synapse formation (Sanes and Yamagata, 2009; Williams et al., 2010). Synaptic components are enriched at pre- and post-synaptic terminals in the early stages of synapse development with the help of CAM interactions (Dalva et al., 2007; Chavis and Westbrook, 2001). During the later stages of synapse development and in mature synapses, CAMs regulate synaptic structure and function.

\section{Neurexin and neuroligin}

Neurexins (Nrxs) and neuroligins (NLs) form one of the best studied molecule pairs in the CAM family. Nrxs, discovered as receptors for $\alpha$-latrotoxin (Südhof, 2008), are type-I transmembrane proteins localized on the pre-synaptic membrane (Berninghausen et al., 2007). Three different genes coding for Nrxs (Nrx1, 2, 3) are present in mammalian neurons. Each gene is driven by two different promoters, resulting in two transcripts encoding a long form of $\alpha-N r x s$ 1-3 and a short form of $\beta-N r x s$ 1-3 (Baudouin and Scheiffele, 2010). NLs are also type-I proteins found on the post- synaptic membrane. At present, at least 4 (in mice and rats) or 5 (in humans) NL isoforms have been identified (Lisé and El-Husseini, 2006; Jamain et al., 2008). The Nrxs and NLs both contain an extracellular domain that participates in preand post-synaptic interactions and an intracellular domain that is involved in multiple functional interactions and regulation processes (Südhof, 2008; Lisé and El-Husseini, 2006; Craig and Kang, 2007).

Nrxs and NLs interact with each other with high affinity via their extracellular regions (Scheiffele et al., 2000; Comoletti et al., 2006). The crystal structures of Nrxs and NLs indicate that these extracellular parts form a trans-synaptic complex in the synaptic cleft (Araç et al., 2007). The binding of Nrxs and NLs is $\mathrm{Ca}^{2+}$-dependent (Boucard et al., 2005; Chen et al., 2008; Ichtchenko et al., 1995), as confirmed by experiments showing $\mathrm{Ca}^{2+}$-dependent cell-cell adhesion following the mixing of two cell populations separately expressing NL-1 and $\beta-N r x$ (Boucard et al., 2005; Nguyen and Südhof, 1997). Five canonical alternative splice sites are identified in $\alpha-N r x s$ and two in $\beta-N r x s$ (Resnick et al., 2008; Tabuchi and Südhof, 2002), which predict more than a thousand different splicing transcripts for Nrxs (Ullrich et al., 1995; Missler et al., 1998). As shown by electron studies, spliced sequence \#2 (SS2) and \#3 (SS\#3) are located in the core structure of extracellular domain of Nrxs, while SS\#1 and SS\#5 are found in distorted regions (Chen et al., 2011). Different from other splicing sites, SS\#4, which locates between the fifth and sixth laminin-nectin-sex-hormone binding globulin (LNS) domain, displays the most significance to affect the binding affinity to NLs and other proteins among the splicing sites (Boucard et al., 2005; Chih et al., 2006; Reissner et al., 2013). NLs have two alternative splicing sites (splice site A and B) (Ichtchenko et al., 1995). Different splicing variants display distinct frequency of occurrence and region specific expression, indicating their synapse- or cell- specific roles (Ullrich et al., 1995). The binding affinities of Nrxs and NLs are controlled by alternative splicing of both molecules (Comoletti et al., 2006; Boucard et al., 2005; Chih et al., 2006). The $\alpha-N r x s$ and $\beta-N r x s$ both bind to NL1 that lacks splice site $B$, and are independent of SS\#4 in Nrxs. In the presence of splice site B, NL1 binds only to $\beta-N r x s$, but does not bind to $\alpha-N r x s$, without SS\#4 (Boucard et al., 2005). This apparent splice insert dependency of $\mathrm{Nrx} / \mathrm{NL}$ interaction raises a splice-code hypothesis that specific pairings of $\mathrm{Nrx} / \mathrm{NL}$ complex according to their roles at different location (Nam and Chen, 2005; Boucard et al., 2005; Ichtchenko et al., 1995; Chih et al., 2006).

The C-terminal of Nrxs and NLs interact with intracellular scaffolding proteins to mediate pre- and post-synaptic differentiation and function. Nrxs bind CASK $\left(\mathrm{Ca}^{2+} /\right.$ calmodulinactivated Ser-Thr kinase) in the pre-synaptic terminal, while CASK binds Velis/MALs proteins and Mints/X11 proteins (Butz et al., 1998; Borg et al., 1999). In addition, CASK phosphorylates the c-tail of Nrxs in an activity-dependent 
manner (Mukherjee et al., 2008), suggesting that Nrxs link extracellular protein-protein interactions with intracellular signaling cascade. NLs bind to PSD-95 (post-synaptic density-95), which is the core scaffolding protein at glutamatergic synapses. At post-synaptic sites, the NLs/Nrxs interaction causes an increase in PSD-95 clustering and the recruitment of post-synaptic NMDA (N-methyl-D-aspartate) and AMPA ( $\alpha$-amino-3-hydroxy-5-methyl-4-isoxazolepropionic acid) receptors (Nam and Chen, 2005; Heine et al., 2008; Chih et al., 2005; Barrow et al., 2009). Thus, the binding of Nrxs and NLs to their partners, helps to align the pre-synaptic release machinery and post-synaptic receptors.

How exactly the Nrx/NL complex functions at synapses? Initial studies showed that the expression of NLs in nonneuronal cells induces pre-synaptic differentiation at the contacting axons of cultured neurons, whereas expressing $\beta-N r x$ in non-neuronal cells induces post-synaptic differentiation at the contacting dendrites from neurons. The synaptogenic effects of Nrxs are dependent on the LNS domain (Gokce and Südhof, 2013). Overexpression of NLs in cultured neurons increases synapse numbers in a synapsetype and NL-isoform-dependent manner (Chih et al., 2004). For example, overexpression of NL2 in neurons specifically increases the number of inhibitory synapses, but not the excitatory synapses, which is consistent with the preferred localization of NL2 at inhibitory synapses (Chih et al., 2005; Varoqueaux et al., 2004; Levinson et al., 2005). Suppression of NL expression by RNA interference (RNAi) or disruption of $\mathrm{Nrx} / \mathrm{NL}$ interaction consistently reduces the number of synapses (Chih et al., 2005; Levinson et al., 2005). Thus, in vitro studies suggest that $\mathrm{Nrx} / \mathrm{NL}$ interactions promote synapse formation and may be necessary for synapse stability.

In vivo analysis from knockout (KO) mice showed that NLs and Nrxs are essential for synaptic maturation and function (Varoqueaux et al., 2006; Missler et al., 2003; Chubykin et al., 2007). The a-Nrx KO mice show significant impairments in $\mathrm{Ca}^{2+}$-triggered neurotransmitter release at both excitatory and inhibitory synapses, possibly due to effects on the pre-synaptic organization of voltage-gated $\mathrm{Ca}^{2}$ ${ }^{+}$channels (Missler et al., 2003). KO of NL1 in mice reduces the synaptic strength at excitatory synapses, whereas the neurons lacking NL2 show synaptic dysfunction at inhibitory synapses. NL1-3 triple KO mice are neonatal lethal, and massive synaptic impairments have been observed from both in vitro and in situ analysis of these mice. KO of NL1-3 in neurons has no effect on the density of synapses in either the brain or in cultured neurons. However, the expression levels of many synaptic proteins, and the basal synaptic transmission and neural network activity are severely impaired (Varoqueaux et al., 2006). These data suggest that Nrxs and NLs are important in maintaining the basal synaptic transmission. In addition, Nrxs and NLs also contribute to the long-term plasticity of synapses via an activity-dependent mechanism (Varoqueaux et al., 2004). The hippocampal dentate gyrus shows inhibition of long-term potentiation
(LTP) in NL1-Null mice (Jedlicka et al., 2013). Constitutive inclusion of an alternatively SS4 in Nrx-3 impairs the recruitment of the post-synaptic AMPA receptor (AMPAR) in mice during NMDA receptor (NMDAR)-dependent LTP (Aoto et al., 2013).

The results showing NL1 and NL2 act on excitatory and inhibitory synapses, respectively suggests an attractive hypothesis; namely, that the excitation/inhibition ratio could be regulated by relative expression levels of NL1 and NL2. Indeed, the amounts of NL1 and NL2 in glutamatergic and GABAergic synapses are restricted by small extracellular splice insertions. The GABAergic associated $\mathrm{NL}$ isoforms bind to $\alpha-N r x 1$ and a subset of $\beta-N r x 1$, resulting in GABAergic but not glutamatergic post-synaptic differentiation (Chih et al., 2006). Together, Nrx/NL interactions are sufficient but not absolutely required for synapse formation, as revealed by other $\mathrm{KO}$ studies. Other CAM proteins may therefore contribute redundant intercellular functions.

\section{LRRTMs}

The LRRTM proteins are a group of brain-enriched type-I transmembrane proteins that contain extracellular leucinerich repeats and a short cytoplasmic tail. Four known LRRTMs are recognized (LRRTM 1-4) and are mainly located at excitatory synapses. The LRRTM family is expressed in both developing and adult brains and is especially enriched in the post-synaptic density (PSD) (Laurén et al., 2003). Non-neuronal cells expressing LRRTMs induce pre-synaptic differentiation when co-cultured with hippocampal neurons (Linhoff et al., 2009). In vitro assays identify that knocking down LRRTM2 reduces, whereas overexpression of LRRTM2 increases, the number of excitatory synapses, but not inhibitory synapses (de Wit et al., 2009; Ko et al., 2009). The extracellular LRR domain of LRRTM2 is considered to induce this excitatory pre-synaptic differentiation (Siddiqui et al., 2013). LRRTM4-Null dentate gyrus granule cells show reduced numbers of excitatory synapses and impairments in both miniature and action-potential-evoked synaptic transmission at excitatory synapses (Siddiqui et al., 2013). Recently, both $\alpha$ - and $\beta$ Nrxs were identified as LRRTM2 ligands. Although the LRRTM-Nrx interaction plays a key role in regulating excitatory synapse formation, the binding of LRRTMs to Nrxs has a distinct regulatory mechanism that involves NLs. LRRTM2 only binds to Nrxs that lack an insert in SS\#4 whereas NLs bind to Nrxs regardless of the presence or absence of an insert in SS\#4. Recombinant $\beta-N r x 1$ also blocks LRRTMs/ Nrxs binding (Ko et al., 2009).

Since LRRTMs and NLs can both bind to Nrxs, an interesting question is raised regarding whether LRRTMs and NLs are functionally redundant, cooperative, or antagonistic. Single, double, or triple knockdowns of LRRTM1, LRRTM2, and NL-3 in cultured hippocampal neurons have no effect on synapse numbers, whereas triple knockdown (TKD) of two 
LRRTMs and NL-3 in cultured NL-1 KO neurons leads to a $\sim 40 \%$ reduction in excitatory synapses (Ko et al., 2011). Knockdown of LRRTM1 and LRRTM2 selectively reduces AMPA receptor-mediated synaptic currents, while knockdown of both LRRTMs, together with NL-3, reduce AMPAR and NMDAR-mediated currents in NL-1 deficiency mice in synapses forming stage (Soler-Llavina et al., 2011). Knockdown of NL-3 at the early stages of synapse formation has no effect on excitatory synaptic transmission regardless of NL-1 expression. These data clearly suggest a functional redundancy between NLs and LRRTMs in developing excitatory synapses. However, LRRTMs and NLs may act differently in mature synapses. For example, inactivation of LRRTM expression, starting from P21 to P35-40, has no effect on excitatory synaptic transmission, while knockout of NL1 reduces the NMDAR/AMPAR ratio at similar ages (Soler-Llavina et al., 2011). In addition, mice lacking LRRTM1 exhibit an increase in the size of pre-synaptic terminals in the hippocampal CA1 region, and an extraordinary phenotype where the animals show avoidance of small enclosures, an increase in social interaction, and a decrease in nest building (Linhoff et al., 2009; Voikar et al., 2013). In acute hippocampal slices, double knockdown of LRRTM1 and LRRTM2 impairs LTP, which can be rescued by the expression of the LRRTM2 extracellular domain (Soler-Llavina et al., 2013). These results indicate that LRRTMs not only play a key role in synapse development and maturation, but also are directly involved in synaptic transmission and more complicated behaviors.

\section{$\mathrm{N}$-cadherin/ $\beta$-catenin}

Cadherins, a large superfamily of CAMs (more than 100 members in humans), are grouped into subfamilies of classic cadherins and protocadherins. These are also transmembrane proteins containing an extracellular domain with a repeated "cadherin motif" or "cadherin repeat" sequence (Takeichi, 1988).

$\mathrm{N}$-cadherin is the most abundant cadherin in excitatory synapses in the brain. It has five extracellular cadherin motifs and a highly conserved cytoplasmic domain that can bind $\beta$ catenin and p120-catenin (Takeichi, 1988; Takeichi, 2007). $\mathrm{N}$-cadherin mediates $\mathrm{Ca}^{2+}$-dependent homophilic protein interactions (Hirano and Takeichi, 2012). During synaptic maturation, the location of $\mathrm{N}$-cadherin shifts from the cleft of the synapses to the outer rims of the active zone (Uchida et al., 1996; Fannon and Colman, 1996). Synapse maturation in the active zone is associated with the clustering of $\mathrm{N}$-cadherin at puncta adherentia junctions (PAJs) (Benson and Tanaka, 1998; Tallafuss et al., 2010).

Classical cadherins bind to $\beta$-catenin at its central armadillo repeat domain, and $\beta$-catenin interacts with the actin cytoskeleton through $\alpha$-catenin. Functional studies reveal important synaptic functions of cadherins and $\beta$-catenin, especially at the excitatory synapses. Cultured neurons lacking
$\mathrm{N}$-cadherin or $\beta$-catenin show impairments in the development of post-synaptic spines, including reduced spine number, more filopodia-like spines, thinner spines, or spines with smaller heads (Mendez et al., 2010; Saglietti et al., 2007; Okuda et al., 2007). Hippocampal conditional KO mice show reductions in the stability of coordinated spine enlargement and LTP in the CA1 region, with spine density, morphology, and basal synaptic neurotransmission untouched (Bozdagi et al., 2010). The LTP-induced long-term stabilization of synapses is also impaired in expression mutants or knockdown of $\mathrm{N}$-cadherin (Mendez et al., 2010). The cooperation between $\mathrm{NL} 1$ and $\mathrm{N}$-cadherin has recently been revealed to promote the formation of glutamatergic synapses in hippocampal cultures and control vesicle clustering at nascent synapses (Aiga et al., 2011; Stan et al., 2010). N-cadherin is also thought to interact with the AMPA receptor subunit GluA2, thereby regulating the expression and trafficking of AMPARs (Saglietti et al., 2007; Nuriya and Huganir, 2006). These results suggest that $\mathrm{N}$-cadherin-mediating adhesion may be responsible for dendritic spine stabilization and synaptic transmission. In primary hippocampal cultures, the suppression of $\beta$-catenin expression decreases the amplitude but not the frequency of spontaneous excitatory synaptic currents. Similar treatment impairs synaptic scaling induced by a two-day blockade of neural activity with tetrodotoxin or bicuculline (Okuda et al., 2007). Down regulation of acetylcholine receptor (AChR) clustering by $\beta$-catenin also results in an inhibition of postsynaptic differentiation at the neuromuscular junction (Wang and Luo, 2008).

Beyond the post-synaptic functions, $\mathrm{N}$-cadherin and $\beta$-catenin are also involved in regulating pre-synaptic vesicle exocytosis. Overexpression of the extracellular domain of $\mathrm{N}$-cadherin increases the frequency of miniature excitatory post-synaptic currents (mEPSCs) (Saglietti et al., 2007). The absence of $\mathrm{N}$-cadherin dramatically impairs short-term plasticity from facilitation to depression at glutamatergic synapses (Jüngling et al., 2006). Mice deficient in $\beta$-catenin show a reduction in the number of reserved pool vesicles and impairment in their response to prolonged repetitive stimulation (Bamji et al., 2003). Recently, axonal knockdown of $\beta$-catenin has been shown to affect the dynamics of vesicle release (Taylor et al., 2013). Therefore, N-cadherin and $\beta$-catenin are structurally and functionally linked in the processes of synapse stabilization as well as in the processes of synaptic transmission from both sides of the synapses. Since the $\mathrm{N}$-cadherin/ $\beta$-catenin complex stands at the intersection between pre- and post-synaptic functions, it is important to investigate more for better understanding their functions to connect synaptic sides together.

\section{Ephrins and Eph receptors}

Eph receptors (EphA and $B$ ) represent the largest family of receptor tyrosine kinases. Eph receptors contain an extracellular domain that comprises a globular ephrin ligand- 
binding domain, a cysteine-rich region, and two fibronectin type III domains; a cytoplasmic domain composed of a juxtamembrane region with two conserved tyrosine residues; a tyrosine kinase domain; a sterile alpha motif (SAM); and a PDZ-binding motif (Kullander and Klein, 2002; Himanen, 2012). EphA receptors bind to glycosylphosphatidylinositol (GPI)-anchored proteins ephrinA, while EphB receptors bind to transmembrane ephrinB ligands. EphA4, a known exception, can bind to both classes of ephrins. Eph and ephrin expressions are not restricted to synapses: they are found at both the pre- and post-synaptic membranes, and also, at least some isoforms, on astrocytes (Klein, 2009). Eph signaling functions in both developing and mature synapses. Eph-ephrin interaction also could mediate signal transductions between the receptor-expressing cells and the ligand-expressing cells in a bidirectional manner (Daar, 2012).

Eph and ephrin signaling is involved in many regulation processes, including axon guidance and cell migration (Davy and Soriano, 2005; Xu and Henkemeyer, 2012; Egea and Klein, 2007). The activation of cyclin-dependent kinase 5 (Cdk5) and ephexin1 by ephrin-A1 promotes EphA4dependent spine retraction, followed by a scaling-down of excitatory synaptic strength (Fu et al., 2007; Peng et al., 2013). EphA4 also inhibits integrin signaling pathways (Bourgin et al., 2007), and EphA4 activation by ephrin-A3 reduces tyrosine phosphorylation of the scaffolding protein Crk-associated substrate (Cas), the tyrosine kinase focal adhesion kinase (FAK), and proline-rich tyrosine kinase 2 (Pyk2) while down-regulating the association of Cas with the Src family kinase Fyn and the adaptor Crk. The EphA4 receptor linked with spine-associated RapGAP (SPAR), which is activated by GTPase, regulates the activities of the Rap GTPase, and therefore neuronal morphology (Richter et al., 2007). Cortical neurons with enhanced expression levels of EphA4 show increased numbers of mature spines (Clifford et al., 2011). EphA4 KO mice are disorganized, confirming an involvement of EphA4 forward signaling in the process of dendritic spine maturation (Murai et al., 2003). Remodeling of the spines by the EphA receptor rearranges the distribution of F-actin in spines (Zhou et al., 2012).

EphA-ephrinA signaling shapes the synaptic strength in addition to regulating cell morphology (Hruska and Dalva, 2012). The activation of EphA4 decreases synaptic and surface GluR1 and attenuates mEPSCs amplitude through an APC (Cdh1)-dependent degradation pathway (Fu et al., 2011). The Eph4-deficient hippocampal CA1 region shows impairment of LTP and long-term depression (LTD); this impairment is independent of the cytoplasmic domain of Eph4, suggesting that ephrinBs are the active signaling partners (Grunwald et al., 2004). Amygdala neurons also have a requirement for EphA4 for synaptic plasticity. Rin1, a brain-specific Rab5-GEF, mediates EphA4 endocytosis and down-regulates EphA4 signaling, which in turn affects LTP (Deininger et al., 2008). Post-synaptic expression of EphA4 and its ligand ephrin-A3 in astrocytes mediates neuron-glia interactions, which are also required for LTP expression at CA3-CA1 synapses in the hippocampus (Filosa et al., 2009).

EphB-ephrinB signaling at synapses is also well studied. EphrinB3 expression is related to glutamatergic synapse density on the dendritic shafts, but not on the spines (Aoto et al., 2007). EphrinB binding to the EphB receptor elevates excitatory synapse formation via degradation of Ephexin5, a RhoA guanine nucleotide exchange factor (Margolis et al., 2010). Suppression of the expression of the EphB receptor reduces excitatory glutamatergic synapses and the clustering of NMDARs and AMPARs, and alters dendritic spine formation as well (Henkemeyer et al., 2003). The PDZ domain of EphB2 also controls localization of the AMPA-type glutamate receptor, while the ephrin binding domain of EphB2 initiates pre-synaptic differentiation (Kayser et al., 2006). EphBs are thought to control synaptogenesis by associating the motility of filopodia and the binding ability of ephrin (Kayser et al., 2008). The Rho-GEF kalirin, Rac1, and its effector PAK are involved in the ephrinB-EphB signaling pathway during spine development (Penzes et al., 2003). Tiam1, a Rac1 guanine nucleotide exchange factor, is phosphorylated by EphBs and promotes Rac1-dependent actin cytoskeletal remodeling for dendritic spine morphogenesis (Tolias et al., 2007). Together, these data indicate that EphB-ephrinB signaling promotes excitatory synaptogenesis.

In addition to its synaptogenesis function, EphB-ephrinB signaling also plays an important role in regulating synaptic plasticity. The suppression of EphB2 expression by siRNA in the post-synaptic neuron reduces mEPSCs frequency in cultured cortical neurons (Kayser et al., 2006). EphB2 deficient mice show reduced NMDA-mediated synaptic responses and impaired LTP (Henderson et al., 2001). This impairment of LTP can be rescued by expressing C-terminal truncated EphB2, indicating that EphB2 kinase signaling is not responsible for these functions (Grunwald et al., 2001). The tyrosine phosphorylation sites in ephrinB2 are necessary for maintaining LTP but not LTD, whereas the C-terminal PDZ interaction site is required for both (Bouzioukh et al., 2007). EphrinB3-deficient mice show reduced amplitude of mEPSCs, but increased NMDA/AMPA ratios in CA1 neurons (Antion et al., 2010). Blocking the interaction between EphRs and the PDZ protein GRIP or extracellular application of soluble forms of B-ephrins (which are pre-synaptic ligands for the EphB receptors) reduces mossy fiber LTPs in the CA3 region, suggesting a requirement for trans-synaptic interactions between post-synaptic EphB receptors and presynaptic B-ephrins (Contractor et al., 2002). Replacement of the cytoplasmic $\mathrm{C}$-terminal signaling domain of the ephrinB3 with $\beta$-galactosidase selectively blocks mossy fiber LTPs (Armstrong et al., 2006). Therefore, trans-synaptic ephrin-Eph adhesion regulates synaptic maturation and plasticity in a bidirectional way in both developing and adult brains. 


\section{NCAM}

The neural cell adhesion molecule (NCAM) is a glycoprotein of the immunoglobulin (lg) superfamily, expressed in both the pre- and post-synaptic membranes. The extracellular part of NCAM has five Ig domains that bind to NCAM, and two fibronectin type III (FNIII) domains related to neurite outgrowth. At least 27 alternatively spliced NCAM mRNAs are present in rat brain, suggesting wide and diverse functions of NCAM (Reyes et al., 1991).

Numerous studies have shown that NCAM regulates synapse formation, maturation, and function through homoand hetero-philic interactions (Bukalo and Dityatev, 2012). The ablation of NCAM reduces the number of synapses (Dityatev et al., 2000). NCAM controls axonal branching and button formation in GABAergic synapses in basket interneurons (Chattopadhyaya et al., 2013). NCAM associates with the post-synaptic spectrin-based scaffold to form a complex that is responsible for recruiting NMDARs and $\mathrm{Ca}^{2+} /$ calmodulin-dependent protein kinase II alpha (CaMKIlalpha) to synapses and is important for NMDAR-dependent LTP and LTD (Sytnyk et al., 2006; Bukalo et al., 2004; Muller et al., 1996). Therefore, NCAM recruits the NMDAR and other PSD components for both synapse formation and synaptic plasticity.

NCAM also has pre-synaptic functions. Deleting NCAM at the neuromuscular junction (NMJ) leads to smaller NMJs and impaired accumulation of pre-synaptic proteins. The number of docked vesicles is reduced and the paired-pulse facilitation (PPF) is lacking at NCAM null junctions (Rafuse et al., 2000). Multiple alterations including vesicle mobilization/cycling in pre-synaptic terminals are also observed in NCAM-deficient mice (Polo-Parada et al., 2001). The C-terminal of NCAM plays a key role in maintaining effective transmission via a pathway involving myosin light chain kinase (MLCK) and probably MLC and myosin II (Polo-Parada et al., 2005). This pathway is thought to control the replenishment of synaptic vesicles during high levels of exocytosis through the facilitation of myosin-driven delivery of vesicles to active zones for subsequent exocytosis. Chromaffin cells show impairment of catecholamine granule trafficking between the readily releasable pool and the highly release-competent immediately releasable pool in the absence of NCAM, resulting in a reduced rate of granule fusion under physiological stimulation. These findings suggest that NCAM is involved in vesicle recycling in both neuronal and endocrine cells (Chan et al., 2005).

\section{L1-CAMs}

The $L 1$ is a family of transmembrane proteins, known as neuronal cell adhesion molecules (L1-CAMs). At least four members are recognized in vertebrates: L1CAM, Close Homolog of L1 (CHL1), NgCAM-related cell adhesion molecule (NrCAM), and Neurofascin. L1CAM contains an ectodomain with six Ig-like domains and five fibronectin type
III repeats, followed by a transmembrane region and a highly conserved cytoplasmic tail (Moos et al., 1988). The intracellular domain of L1 interacts with many other synaptic organizers, including ankyrin, actin, spectrin, and 14-3-3 proteins (Hortsch et al., 2009; Ramser et al., 2010; Herron et al., 2009; Loers and Schachner, 2007). The L1-CAMs are involved in many neuronal functions, including axonal guidance, neurite outgrowth and fasciculation, and cell migration (Chang et al., 1987; Lindner et al., 1983; Fischer et al., 1986; Maness and Schachner, 2007).

L1-deficient mice show a significant reduction in frequency, but not amplitude, of miniature inhibitory post-synaptic currents (mIPSCs), and a reduction in the mean amplitude of putative unitary IPSCs, whereas the basal excitatory synaptic transmission is normal (Saghatelyan et al., 2004). However, the conditional inactivation of L1 in the adult brain increases the basal excitatory synaptic transmission and decreases anxiety in the open field, which differs from the response seen in $\mathrm{L} 1$ constitutive $\mathrm{KO}$ mice (Law et al., 2003). These differences might arise from the developmental function of $L 1$, as no structural abnormalities in morphology are observed in these mice when compared to constitutive $\mathrm{KO}$ mice. The L1/ankyrin interactions are important in regulating the functions of inhibitory synapses. The ankyrin-mediated localization of L1CAMs is implicated in the organization of GABAergic synapses in Purkinje neurons (Ango et al., 2004). Loss of the L1/ankyrin interaction impairs branching of GABAergic interneurons and specifically reduces the number of perisomatic synapses (Guan and Maness, 2010).

CHL1, another member of the L1 subfamily, has a reported involvement in synaptogenesis of inhibitory interneurons, although it functions differently from L1. The hippocampal CA1 region in juvenile CHL1 mutant mice shows an increase in inhibitory post-synaptic currents and a decrease in LTP at CA3-CA1 excitatory synapses. The length and linear density of active zones, and the numbers of perisomatic puncta containing inhibitory axonal markers, are also increased (Nikonenko et al., 2006). CHL1-deficient mice show enhancement of basal synaptic transmission in the lateral and medial perforant path projections to the dentate gyrus, whereas reactivity to environmental stimuli and expression of social behaviors are reduced (Morellini et al., 2007). CHL1 also maintains inhibitory synapses between stellate axons and Purkinje dendrites, indicating a role in connecting glia and neuron (Ango et al., 2008).

IgCAMs, including the previously mentioned NCAM and L1CAM, are capable of binding in both trans- and cis- orientations. Early structural studies identified the involvement of the multiple Ig domains of NCAM and L1 in trans binding (Bateman et al., 1996; De Angelis et al., 1999; Jensen et al., 1999). Both NCAM and L1 family members could be palmitoylated and targeted to lipid rafts, indicating cis interactions between these CAMs (Little et al., 1998; Ren and Bennett, 1998). NCAM and L1 can stimulate neurite growth via a 
mitogen-activated protein kinase (MAPK) dependent pathway. In PC12 cells, the MAP kinase extracellular signalregulated kinases ERK1 and ERK2 are phosphorylated through interaction of NCAM with a synthetic NCAM peptide ligand (Kolkova et al., 2000). In 3T3 cells, L1 cross-linking can activate ERK2, a component of the MAPK cascade (Schaefer et al., 1999). The fibroblast growth factor (FGF) receptor is also proposed to share downstream signaling pathways with CAMs during the stimulation of neurite growth (Kolkova et al., 2000).

These CAMs transduce signals from outside to inside, but they also can transduce signals in the opposite direction because of their functions in cell migration and synaptic plasticity. For example, L1 can bind ankyrin, resulting in oligomerization of CAMs and an enhancement of homophilic trans-adhesion on the membrane (Tuvia et al., 1997). Different members of L1CAMs can interact with ankyrin to form hetero-oligomers with different affinities, and different regulation by homophilic or heterophilic ligand binding to the CAMs (Malhotra et al., 1998). Together, the CAMs mediate the adhesion response to external stimuli, and inside-out signaling transduction.

\section{Nectins}

Nectins are $\mathrm{Ca}^{2+}$-independent lg-CAMs (Takai et al., 2003). At present, four nectins have been identified in humans. All nectins can form homo-cis dimers followed by trans-interaction in an either heterophilic or homophilic manner through their extracellular domains (Mizoguchi et al., 2002). Nectin-3 interacts with Nectin-1 or -2 to form a hetero-trans-dimer with a higher binding ability than homo-trans-dimers (Rikitake et al., 2012).

Nectins interact with actin-binding protein afadin, an a-catenin interacting protein, through the C-terminal PDZ binding domain, which predicts an involvement with the cadherin/catenin adhesion complex (Giagtzoglou et al., 2009). Nectin-1 and afadin form clusters at developing synapses, and these clusters colocalize with the $\mathrm{N}$-cadherincatenin complex, implying a role of these two bimolecular pairs during initial synapse formation. Similar to N-cadherin, Nectin-1 mainly locates at matured excitatory synapses although it is initially found at both excitatory and inhibitory synapses (Lim et al., 2008). The CA3 area of the adult hippocampus shows an asymmetric localization of Nectin-1 and -3 at the pre- and post-synaptic sides, in contrast to the symmetrically localization of afadin expression. Reduction in nectin-based adhesion leads to a decrease in synapse size and an accompanying increase in synapse number, suggesting a role of the nectin-afadin system in synaptogenesis (Mizoguchi et al., 2002). Mice deficient in either Nectin-1 or Nectin-3 show a reduced number of puncta adherentia junctions (PAJs) and abnormal mossy fiber trajectory (Honda et al., 2006). Nectin-1, but not Nectin-3, plays a role in increasing contextual fear memory (Fantin et al., 2013).
On the other hand, conditional absence of afadin largely reduces the signal of nectins, $\mathrm{N}$-cadherin, and $\beta$-catenin, and disrupts PAJs, whereas it increases the numbers of perforated synapses. Thus the nectin-afadin interaction appears to participate in synaptic remodeling by regulating the stability of synaptic junctions (Majima et al., 2009).

The nectin-afadin complex also interacts with many synaptic proteins that function at synapses. The synaptic scaffolding molecule (S-SCAM) has been reported to colocalize with nectins via the PDZ domain-binding domain of the latter (Yamada et al., 2003). S-SCAM is involved in the pre-synaptic vesicle clustering mediated by $\mathrm{N}$-cadherin and NL-1 cooperation (Stan et al., 2010). NL-1 induces the release probability and enhances mEPSCs frequency in the presence of $\mathrm{N}$-cadherin. Several cell adhesion molecules therefore can function either separately or synergistically in synapse maturation (Sakisaka et al., 2007).

\section{Contactins}

Contactins (CNTN) are a group of GPI-linked Ig-CAMs containing six $\mathrm{N}$-terminal Ig-like domains and four fibronectin III-like domains. Six members are recognized in the CNTN family: CNTN-1, CNTN-2/TAG-1, CNTN-3/BIG-1, CNTN-4/ BIG-2, CNTN-5/NB2, and CNTN-6/NB3. CNTNs play an important role in the formation of axon connections in the developing nervous system. Both CNTN-1 and CNTN-2 are involved in axon growth and guidance (Buttiglione et al., 1996; Perrin et al., 2001). CNTN-6 is prominently expressed pre-synaptically in the developing nervous system. Hippocampal neurons show co-expression of CNTN-6 with the excitatory synaptic markers vesicular glutamate transporter 1 (VGLUT1) and 2 (VGLUT2), but not with the inhibitory synapse marker vesicular GABA transporter (VGAT). CNTN-6 deficient mice show increased numbers of immature granule cells in the internal granule cell layer (IGL) and a decreased density of parallel fiber synaptic terminals in the cerebellum (Sakurai et al., 2009). KO of CNTN-6 selectively reduces excitatory but not inhibitory synapse density (Sakurai et al., 2010). Thus, CNTN-6 seems to be required for postnatal glutamatergic synapse development. CNTN 4 and 5 are also involved in synapse differentiation, especially at early stages. CNTN-4 extends the length of neurites, while CNTN-5 increases the number of roots (Mercati et al., 2013). Unlike the pre-synaptic localization of CNTN-6, CNTN-1 has been detected in PSD in CA1 pyramidal cells. Inactivation of CNTN-1 expression leaves the basal transmission and LTP level intact, without altering synaptic morphology either (Murai et al., 2002), but PPF and NMDA receptor-dependent LTD are impaired in these mice. In adult mice, overexpression of contactin increases LTP and spatial and object recognition memory (Puzzo et al., 2013). CNTNs may therefore function at both pre- and post-synaptic sites, although the mechanisms remain unclear. 


\section{SynCAM}

Synaptic cell adhesion molecules (SynCAM) have been identified as a family of proteins that contain three extracellular Ig-like domains, a single transmembrane domain and a cytoplasmic tail (Thomas et al., 2008). Four SynCAM isoforms are recognized: SynCAMs $1-4$. All SynCAMs are highly enriched in the brain, and SynCAM 1 is also found in the lung and testis (Fogel et al., 2007). Like the NLs, SynCAM recruits synaptic proteins and promotes neuron differentiation pre-synaptically in co-culture assays (Sara et al., 2005). During synapse development, SynCAMs are located in both pre- and postsynaptic plasma membranes and undergo homo- and heterophilic adhesive interactions. Interestingly, unlike NCAM and L1CAM, SynCAMs are preferentially assembled into heterophilic rather than homophilic complexes. SynCAMs 1 and 2 bind to each other across the synaptic cleft to form a transsynaptic SynCAM 1/2 complex that is subject to glycosylation modifications (Fogel et al., 2007). The number of pre-synaptic terminals and the level of excitatory synaptic transmission are increased via the binding of SynCAM 1 and 2 (Fogel et al., 2007; Sara et al., 2005). Consistently, loss of SynCAM 1 decreases excitatory synapse number in the nucleus accumbens (Giza et al., 2013). Lateral self-assembly of SynCAM 1 has also been reported. This lateral interaction is required for synaptogenic activity in immature neurons, while restricting synaptic size in mature synapses (Fogel et al., 2011).

In addition to their homo- and hetero-philic interaction, SynCAMs also bind many other proteins via the C-terminal domain. SynCAMs bind to the scaffold proteins syntenin and CASK via the C-terminal PDZ domain, and recruit CASK to the plasma membrane (Biederer et al., 2002). SynCAM1 also binds to protein $4.1 \mathrm{~B}$ intracellularly, which in turn recruits NMDAR to the post-synaptic plasma membrane, resulting in an increase in the frequency of NMDAR-mediated mEPSCs in cultured hippocampal neurons (Hoy et al., 2009).

In vivo studies have revealed a role for SynCAM 1 in the regulation of synapse numbers and plasticity. Mouse neurons form fewer excitatory synapses in the absence of SynCAM 1, while overexpression of SynCAM 1 results in an increase in excitatory synapse number. The LTD and spatial learning are also regulated by the expression of SynCAM 1 (Robbins et al., 2010).

Although SynCAMs and NLs both function in the presynaptic induction of synapses, the mechanisms underlying this response might be distinct. Co-culture assays show that both spontaneous and evoked neurotransmitter release induced by SynCAM and NLs are indistinguishable. However, electrophysiological analysis reveals that only SynCAM increases the early development of the excitatory neurons by its intracellular cytoplasmic domain. Morphological analysis shows that only NL1 increases the synapse number and spine density (Sara et al., 2005). These contradictions observed in different assays could be reconciled by assuming that the role of SynCAM is to increase the vesicle pool size of previously existing synapses whereas the role of NL1 is to lead synapse formation without altered recruitment of AMPARs in the post-synaptic site or proper assembly of pre-synaptic secretory apparatus. Therefore, proper synaptogenesis probably requires more than just one 'master molecule', with many molecules functioning instead, either separately or in cooperation, in the discrete steps of synapse formation.

\section{SALMs}

Synaptic adhesion-like molecules (SALMs) are a newly discovered family of adhesion molecules: at least five members have been identified in the central nervous system. SALMs 1-3 contain an extracellular region consisting of a leucinerich repeat (LRR), a fibronectin type III domain, Ig-like domains, a transmembrane domain, and a C-terminal PDZbinding motif that interacts with PSD-95. SALMs 4 and 5 lack the PDZ-binding domain (Seabold et al., 2008). SALMs 1-3 bind to each other, while SALMs 4 and 5 form homomeric complexes in brain. Transfected heterologous cells show that only SALMs 4 and 5 form homomeric associations mediated by the extracellular N-terminus (Seabold et al., 2008).

SALMs undergo multiple interactions with other proteins. SALM1 interacts with post-synaptic NMDA receptors, possibly through the extracellular or transmembrane regions, and with scaffold proteins PSD-95, SAP 97, and SAP 102 via the PDZ-binding domain. Immunostaining experiments show that SALM1 recruits PSD-95 and NMDA receptors to postsynaptic sites (Wang et al., 2006; Seabold et al., 2012). SALM2 interacts with PSD-95 and other post-synaptic proteins, including guanylate kinase-associated protein (GKAP) and AMPA receptors at excitatory synapses (Ko et al., 2006). SALM3 and SALM5 recruit VGluT and VGAT (which are presynaptic proteins localized at excitatory and inhibitory synapses, respectively), the pre-synaptic vesicle protein synaptophysin, and the pre-synaptic active zone protein Piccolo, although SALM3 has higher affinity for complex formation with PSD-95 compared to SALM5 (Mah et al., 2010). Functional assays revealed that overexpression of SALMs promotes neurite outgrowth in cultured neurons (Wang et al., 2008). Suppression of SALM2 expression decreases the number of excitatory synapses and dendritic spines, and selectively reduces the frequency but not the amplitude of mEPSCs (Ko et al., 2006). On the other hand, knockdown of SALM5 significantly reduces both spontaneous excitatory and inhibitory synaptic transmissions, affecting both frequency and amplitude (Mah et al., 2010). Thus, SALMs regulate excitatory and inhibitory synapse function through distinct mechanisms.

\section{NGLs}

NGL (netrin-G ligand) proteins are a family of LRR-containing CAMs consisting of three members: NGL1-3. NGLs are 
mainly located post-synaptically at excitatory synapses. NGL-1 and -2 bind to netrin-G1 and netrin-G2 through their cytosolic tails in an isoform-specific manner (Kim et al., 2006). The LRR domain of NGL-3 interacts with pre-synaptic LAR protein to induce synapse formation (Kwon et al., 2010). PTPo interacts with NGL-3 to promote a bidirectional synapse formation, whereas PTPס-NGL-3 interaction induces pre-synaptic differentiation in only a unidirectional manner. Receptor tyrosine phosphatases LAR, the NGL-3 binding partner, is also required for maintaining the number of excitatory synapses and dendritic spines, the expression of surface AMPARs, and the targeting of the cadherin- $\beta$-catenin complex (Dunah et al., 2005).

Cultured neurons overexpressing NGL-2 show an increase in the number of dendritic protrusions. Suppression or competitive inhibition of NGL-2 reduced the number of excitatory synapses (Kim et al., 2006). Suppression of NGL-2 or NGL-3 selectively decreases excitatory synaptic currents (Kim et al., 2006; Woo et al., 2009). In the retina, loss of NGL-2 impairs branching of horizontal cell axons that stratify in the outer plexiform layer and reduces synapse formation between horizontal cell axons and rods (Soto et al., 2013). LAR knockdown reduces both the amplitude and frequency of mEPSCs (Dunah et al., 2005). Thus, like other cell adhesion molecules, NGLs are also involved in synaptic function.

\section{IgLONs}

IgLONs are a group of adhesion molecules with three extracellular C2 domains and a GPI anchor attach to the membrane. Four genes are presently identified in this family: LAMP (limbic system-associated membrane protein), OBCAM (opioid-binding cell adhesion molecule), Ntm (neurotrimin), and Kilon. The LAMP, Ntm, and OBCAM molecules interact homophilically with themselves and heterophilically with each other (Lodge et al., 2000; Gil et al., 2002). During development, IgLONs show both overlapping and distinct patterns in protein localization. For example, Kilon is distributed in axons and pre-synaptic terminals at early stages, but is mainly observed in the post-synaptic sites of dendritic and somatic synapses in adults (Miyata et al., 2003; Hashimoto et al., 2008). LAMP alters its location from restriction at post-synaptic sites to wide expression on somata, dendrites, and axons in the process of maturation (Pimenta et al., 1996).

The IgLONs are implicated in synaptogenesis. Overexpression of LAMP or OBCAM increases synapse number in hippocampal neurons (Hashimoto et al., 2009). Consistently, down regulation of OBCAM expression reduces synapse number, impairing synapse formation (Yamada et al., 2007). OBCAM also regulates neuronal activity via a raft-dependent pathway. Overexpression of Kilon reduces synapse number at early stages but increases the number of dendritic synapses in mature neurons with the alteration of lipid raft dependence (Hashimoto et al., 2008). However, more data are needed to determine the precise nature of the IgLON involvement in synaptic transmission and plasticity.

\section{Integrins}

Integrins are transmembrane receptors found in organisms ranging from sponges to mammals. Integrins form heterodimers with two type-I transmembrane chains, a subunit and $\beta$ subunit. At least eighteen $\alpha$ subunits and eight $\beta$ subunits are known, resulting in 24 unique heterodimers in mammals. Interaction of integrins with other proteins, including cadherins and Ig-CAMs allow transmission of signals across the plasma membrane in both directions and mediate cell-cell and cell-matrix interactions and communication (Hynes, 2002). Some integrin subunits are concentrated at synapses, indicating a role in synaptic function. For example, post-synaptic $\beta 3$ integrin directly interacts with AMPARs in primary hippocampal cultures (Cingolani et al., 2008). In addition, $\beta 3$ integrin binds to the GluA2 subunit of AMPARs through their cytoplasmic tails (Pozo et al., 2012). Through the regulation of AMPAR trafficking, similar to that conducted by $\mathrm{N}$-cadherin, $\beta 3$ integrin is involved in synaptic scaling. $\beta 1$ integrin, another integrin subunit, shows an altered expression in either limbic seizures or muscle stretch (Pinkstaff et al., 1998; Chen and Grinnell, 1995). Deletion of postsynaptic $\beta 1$ integrin increases the expression of $\mathrm{N}$-cadherin and NLs, possibly implying a compensatory effect (Mortillo et al., 2012). Overexpression of $\beta 3$ integrin in the post-synaptic neurons reduces the amplitude of mEPSCs and alters the subunit composition of AMPAR, while inactivation of $\beta 3$ integrin abolishes the synaptic scaling induced by pharmacological silencing of neuronal activity (Harburger and Calderwood, 2009). In addition to cis-regulation, integrins organize the synapse assembly in a trans-synaptic manner. Deleting $\beta 1$ integrin only in the pre-synaptic terminals alters the ratio of mature and immature spines numbers in cultured neurons (Ning et al., 2013).

Homeostatic synaptic scaling requires $\beta 3$ integrin, but the function of this protein in synaptic transmission is still not very clear. Excitatory synaptic currents in primary hippocampal pyramidal neurons are increased or decreased by the overexpression of wild type or dominant-negative $\beta 3$ integrin, respectively (Cingolani et al., 2008). However, expressing $\beta 3$ integrin mutants, including wild-type, in constitutively inactive or constitutively active mutants has no differential effects in excitatory synaptic responses (Pozo et al., 2012). Deletion of $\beta 3$ integrin also leaves LTP, LTD, and short-term plasticity unaltered (McGeachie et al., 2012). More investigations are therefore needed to determine the exact role of integrins in synaptic transmission.

\section{LAR-RPTPs}

Leukocyte antigen-related receptor protein tyrosine phosphatases (LAR-RPTPs) have recently been proposed to 


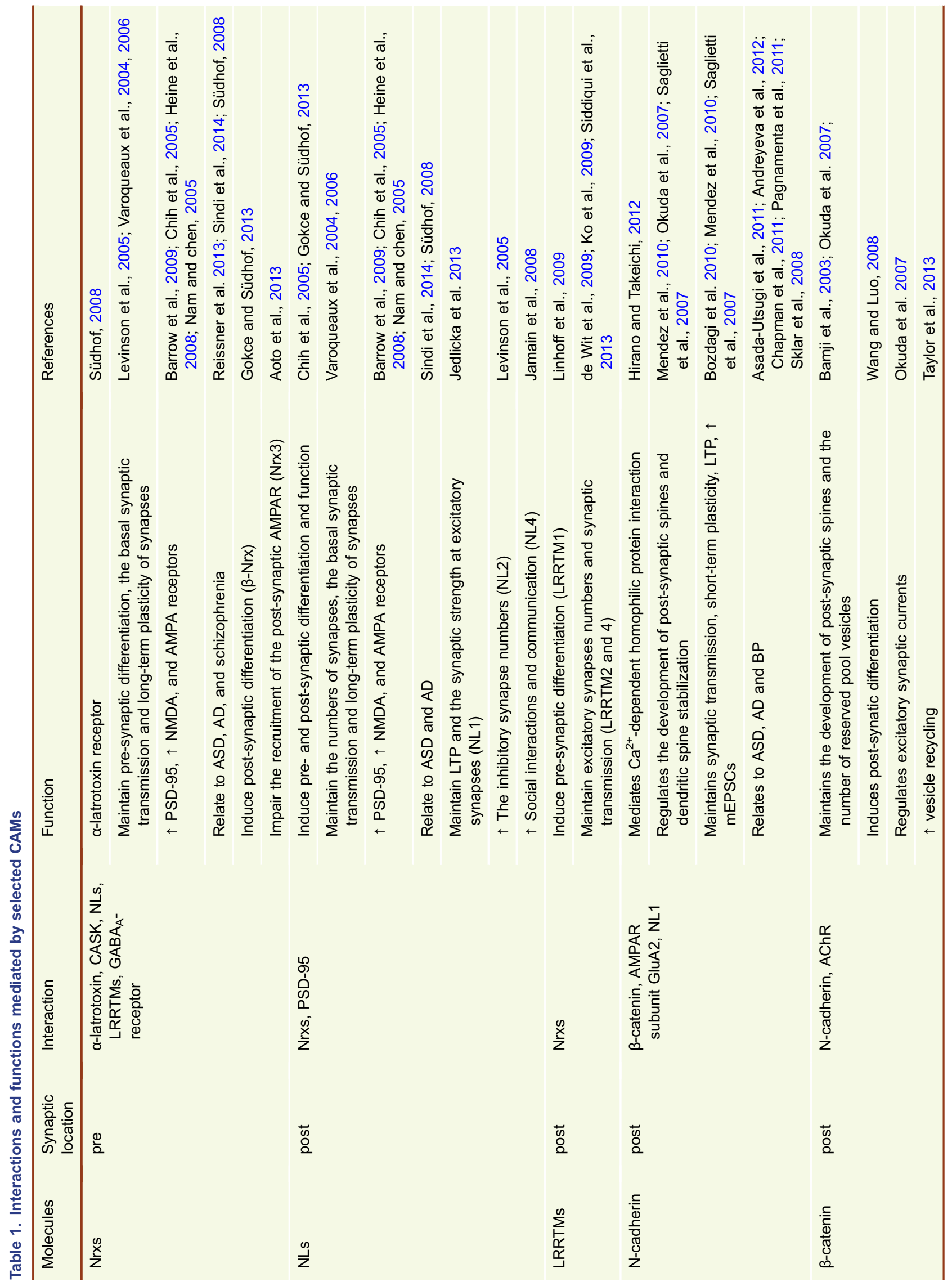




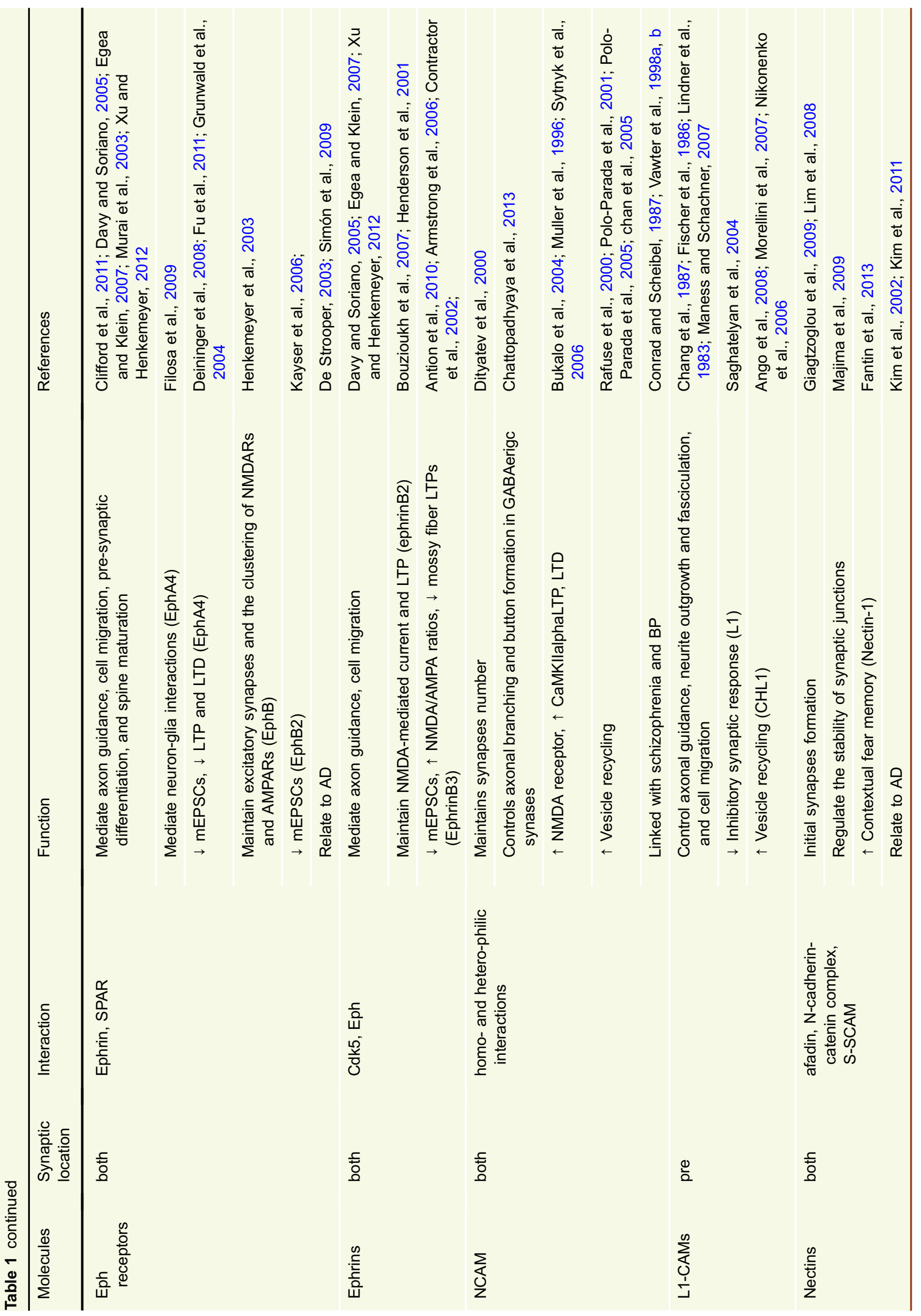




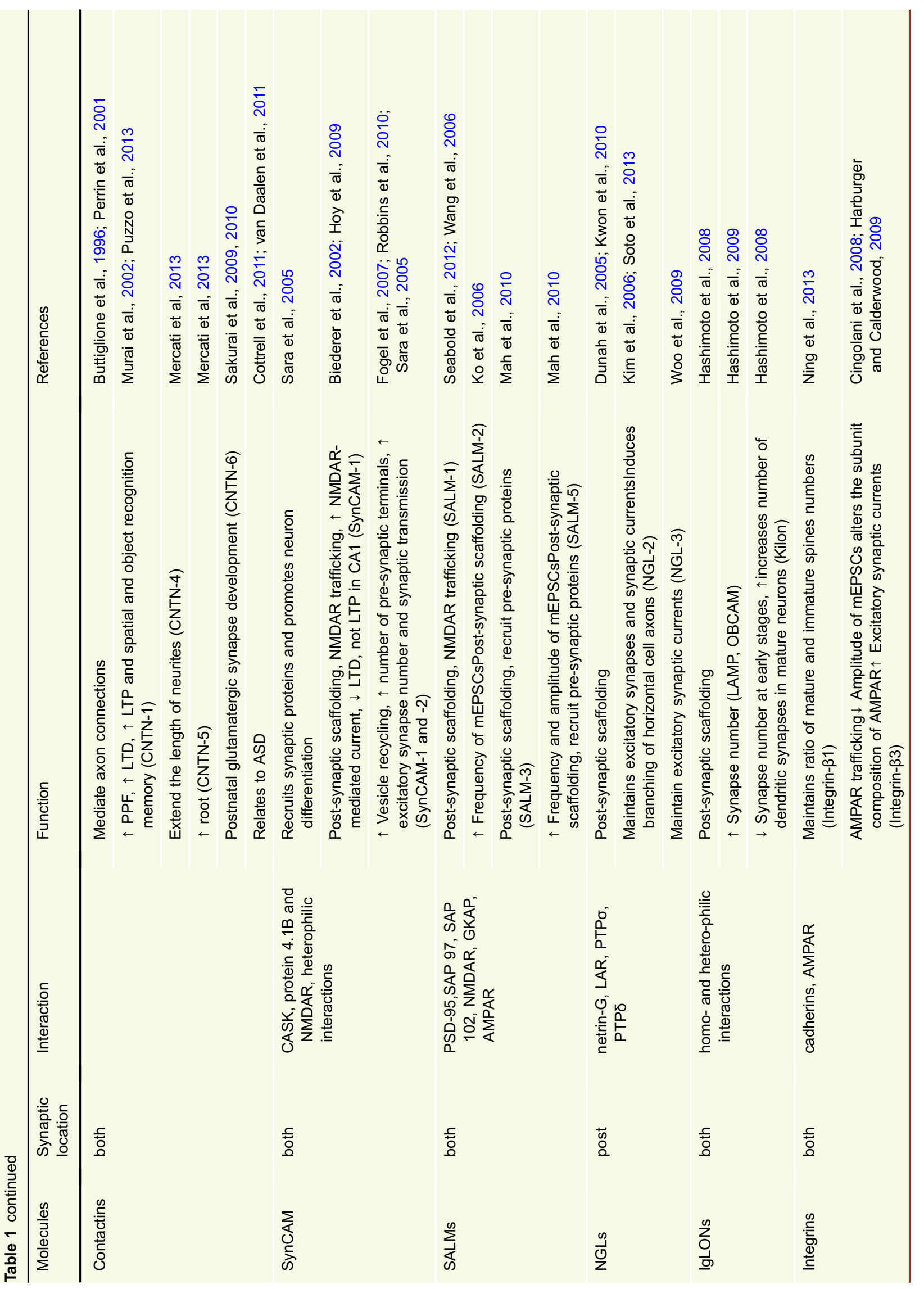




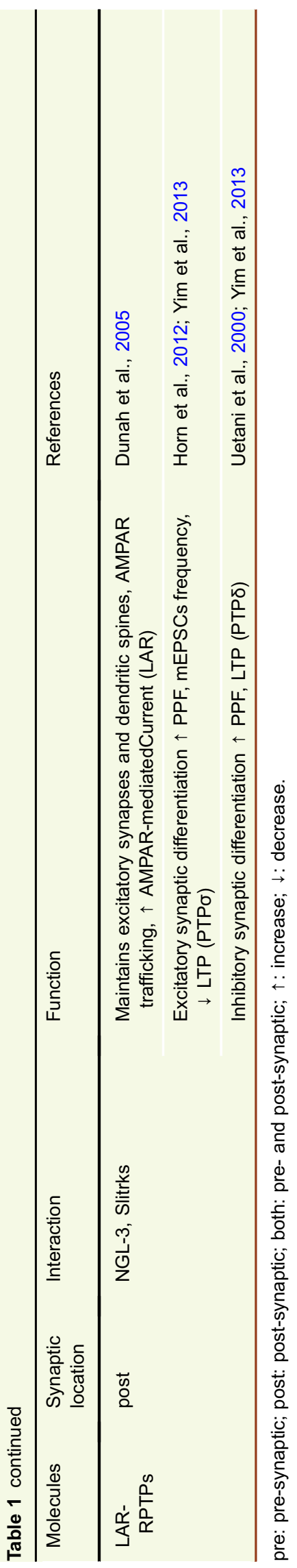

have a role in pre-synaptic development. The LAR-RPTP proteins have a single transmembrane domain, two intracellular PTP domains, and an extracellular domain (Pulido et al., 1995). Three vertebrate members (LAR, PTPס, and PTP $\sigma$ ) and a few invertebrate members have been identified in the family (Chagnon et al., 2004). LAR-RPTPs are widely distributed in the brain. LAR and PTP $\sigma$ are enriched in glutamatergic synapses, and LAR is associated with AMPARs (Wyszynski et al., 2002; Takahashi et al., 2011); whereas PTPס mainly localized in inhibitory synapses (Takahashi et al., 2012). LAR-RPTPs regulate synapse formation via various protein interactions; for instance, PTPo and PTPס are reported to interact with NGL-3 and to promote synapse formation (Kwon et al., 2010). Overexpression of dominant-negative LAR impairs the normal function of $\beta$-catenin-cadherin complex that regulates synaptic differentiation (Brigidi and Bamji, 2011). Similarly, RNAi experiments show a reduction in dendritic targeting of the $\beta$ catenin-cadherin complex, suggesting that LAR-RPTPs function in maintaining excitatory synapses and dendritic spines (Dunah et al., 2005). PTPo and PTPס are required for excitatory and inhibitory synaptic differentiation, respectively, via interactions with Slit- and Trk-like proteins (Slitrks), a family of proteins belonging to the LRR superfamily (Yim et al., 2013).

Electrophysiology studies have revealed synaptic functions for LAR-RPTPs. Excitatory synaptic transmission is dramatically impaired by overexpression of LAR dominantnegative constructs (Dunah et al., 2005). Similarly, loss of LAR-RPTPs reduces the amplitude and frequency of $\mathrm{mE}$ PSCs. Mice deficient in PTPס show increased PPF and LTP in the hippocampus (Uetani et al., 2000). Surprisingly, receptor protein tyrosine phosphatase $\sigma$ (RPTP $\sigma)$ null mice show an increase in PPF and mEPSCs frequency, but reduced LTP (Horn et al., 2012). Activation of LAR-RPTPs results in specific mAChR-LTD, but not mGluR-LTD (Dickinson et al., 2009).

Mice that lack LAR phosphatase domains exhibit spatial learning impairment in performance of the Morris water maze, and are more active in exploration and nest-building (Kolkman et al., 2004). Similar learning impairment has been found in mice lacking PTPס (Uetani et al., 2000). On the contrary, loss of RPTP $\sigma$ in mice causes an enhancement in novel object recognition memory (Horn et al., 2012). Several studies suggest important functions of LAR-RPTPs at synapses, but the underlying mechanisms still remain to be established (Table 1).

\section{CAMS IN NEUROLOGICAL DISORDERS}

The incidence of neurological disorders is increasing in the human population. For example, in 2006, there were 26.6 million AD patients in the world (Brookmeyer et al., 2007). Autism spectrum disorders (ASD), neurodevelopmental disorders, now affects about $1 \%$ of children (Newschaffer et al., 
2007). Most neurological disorders originate as dysfunction of neural circuits, whose function is highly reliant on precisely controlled cell-cell adhesions.

As we discussed above, CAMs, which connect neurons with each other, play a key role in synapse formation and synaptic plasticity. Mounting evidence now connects several neurological disorders with CAMs, as many mutations or aberrant expressions of CAMs are associated with neurological disorders. For example, mutations in Nrxs and NLs are found in ASD patients (Südhof, 2008) and Eph receptor alterations are highly related with $A D$ (Chen et al., 2012). Therefore, research on CAM function will help to provide a better understanding of the mechanisms underlying pathogenic neurological disorders.

\section{CAMs in autism}

ASD are neural development disorders that are often associated with other genetic disorders such as Down syndrome, tuberous sclerosis, and Fragile-X Mental Retardation. ASD are characterized by impairments in social interaction and communication, and stereotypic or repetitive behaviors (Südhof, 2008). ASD alter the connection and organization of nerve cells and their synapses in the brain. Genetic studies have revealed many mutations in CAMs in ASD patients: for example, five ultra-rare structural variants including a predicted splicing mutation have been found in a-Nrx1 gene from 116 Caucasian patients with autism but only one ultra-rare structural variant occurred in controls (Yan et al., 2008). The $\beta-N r x 1$ gene has two putative missense structural variants that were detected in four Caucasian patients with autism and not in healthy controls (Feng et al., 2006). On post-synaptic side, two NL genes (NL3 and 4) located on the $X$-chromosome are associated with autism. Two base pair deletions in NL4 have been found in male autistic patients, resulting in altered interactions with $\beta$-Nrxs (Laumonnier et al., 2004). The R451C and R87 W substitutions in the NL3 and NL4 genes, respectively, have been associated with autistic patients (Comoletti et al., 2004; Zhang et al., 2009). This R451C mutation impairs NL3 trafficking, resulting in lower cell surface expression of NL3 and largely reducing $\beta-\mathrm{Nrx} 1$ binding activity.

Mice with a R451C knock-in show increased spatial learning and impairments in social interactions, accompanied by specific increases in inhibitory synaptic transmission (Tabuchi et al., 2007). The R451C mutation is a gain-offunction substitution because NL3 KO mice did not phenocopy any of the phenotypes observed in the knock-in mice (Tabuchi et al., 2007). The largely decreased cell surface expression of NL3 in R451C mutant mice (Comoletti et al., 2004) indicates that the remaining protein must change synaptic function tremendously. Unlike the R451C knock-in mice, a loss-of-function mutation in the mouse NL4 impairs reciprocal social interactions and communication (Jamain et al., 2008). Thus, both NL3 knock-in and NL4 KO mice display autism-like phenotypes, providing partial animal models for this disorder.

Other CAMs are also involved in autism. Genetic studies shows an involvement of cadherin $10(\mathrm{CDH} 10)$ and cadherin 9 (CDH9) in the pathogenesis of autism (Wang et al. 2009). A scan for the $I Q$ discrepancy in autism revealed a unique truncated cadherin, cadherin $13(\mathrm{CDH} 13)$, which has also been suggested as a candidate for autism (Chapman et al. 2011). A genome-wide recurrent de novo analysis also includes the $\mathrm{CDH} 13$ gene in rare copy-number variations in autism families (Sanders et al. 2011). Cadherin 15 (CDH15) gene has been found in a sporadic patient with autism (Willemsen et al. 2010). Cadherin 8 (CDH8), which presents in the developing human cortex, is reported as an autism susceptibility gene in other recent research (Pagnamenta et al., 2011). A meta-analysis identified several genes close to cadherin with possible links to autism. Protocadherin 10 (PCDH10), which regulates neuronal activity and controls axon outgrowth, is a potential candidate gene for autism (Morrow et al. 2008; Uemura et al. 2007).

CNTN is another family of cell adhesion molecules related to autism. Currently, CNTN4, CNTN5, and CNTN6 are suggested as potential disease genes for autism. First, a deletion at the $5^{\prime}$ end of the CNTN4 gene has been identified in an autism patient (Cottrell et al. 2011). Disruption of the CNTN4 gene causes the $3 p$ deletion syndrome and impairs normal CNS development (Fernandez et al. 2004). Rare copy number variations (CNVs) in CNTN4 have been reported to influence autism susceptibility in Asian populations (Guo et al. 2012). A loss of CNTN5 co-segregated with autism in one family, and one de novo CNV and one noncosegregating inherited CNV in CNTN6 were found in a Utrecht cohort (van Daalen et al. 2011). Current data clearly suggest a link between mutations in different CAMs and autism, but how these mutant proteins give rise to the altered human behavior seen in autism patients is still a mystery.

\section{CAMs in AD}

AD, first defined in 1906 by Alois Alzheimer, is the most common form of dementia, with an increasing risk with age. In Europe, millions of patients suffer from the disease and the numbers of patients are expected to increase dramatically (Di Luca et al. 2011). Multiple neurochemical, neurological, psychological, and physical abnormalities have been reported in $A D$ patients, indicating $A D$ to be a multifactorial disease. It is a slowly progressive disorder, where early memory loss originates from synapse failure before neuron death. Therefore, $A D$ is expected to show a strong relationship with CAMs that play essential roles in intercellular synaptic connections.

One very viable hypothesis suggests that synaptic failure in $A D$ is due to altered synaptic protein composition and function. Ephs and ephrins, which are known to regulate synapse formation and synaptic plasticity, are related with 
cognitive impairments in AD (Chen et al., 2012). The expression and function of Ephrins and Eph receptors changes in $A D$ patients. In $A D$ model mice, abnormal expression of EphA4 and EphB2 are detected much earlier than the decrease in synaptic proteins and the onset of cognitive decline (Simón et al., 2009), indicating that Eph receptors may act as early stage markers of AD. EphA4 has been reported to colocalize with $\mathrm{Y}$-secretase, the key enzyme that cleaves amyloid precursor protein (APP) to generate $A \beta$ (De Strooper 2003); EphA4 is processed by $\mathrm{Y}$-secretase upon synaptic activity (Inoue et al., 2009). At the synapses, $Y$-secretase processes EphA4 to generate EphA4-ICD, a short intracellular domain. However, familial mutations in presenilin 1 (PS1) in AD's patients slow down this process, resulting in a reduced formation of dendritic spines, implying that down-regulated processing of EphA4 may be involved in AD pathogenesis. Moreover, Rac1, which is activated by EphA4-ICD, has been reported to control the activity of the p21-activated kinase (PAK) pathway, leading to memory impairment (Zhao et al., 2006). Indeed, the amount of Rac1 decreases dramatically corresponding with the level of EphA4-ICD in AD patients (Matsui et al., 2012). The processing of the EphB2 receptor is also regulated by $\mathrm{Y}$-secretase and inhibited by familial AD mutations of PS1 (Litterst et al., 2007). The NMDA receptor is phosphorylated by the C-terminal of EphB2, while reduced processing of EphB2 may decrease the cell surface expression of NMDAR, resulting in learning and memory impairment (Xu et al., 2009). The $A \beta$ peptide binds to the extracellular domain of EphB2 and triggers EphB2 degradation in the proteasome, leading to a decrease in surface and total EphB2 in neurons. A lack of EphB2 expression causes neuronal dysfunction and memory impairments through the NMDAR dependent pathway (Cissé et al., 2011). More interestingly, increasing EphB2 level can reverse these impairments.

Many other CAMs are also involved in AD pathogenesis. For example, soluble intercellular adhesion molecule-1 (sICAM-1) levels are higher in patients with AD (Rentzos et al., 2005). A genome-wide late-onset $A D$ analysis associates $\mathrm{PCDH} 11 \mathrm{X}$ with disease in individuals of European descent from the United States (Carrasquillo et al., 2009). The interactions of Nrxs and NLs not only control the balance between excitatory and inhibitory neurotransmitter release, but they also function in $\beta$-amyloid metabolism, suggesting roles in AD (Sindi et al., 2014). Processing of Nrx3 $\beta$ can be altered by several PS1 mutations of the $\mathrm{y}$-secretase that cause early-onset familial AD (Bot et al., 2011). In hippocampal neurons, the accumulation of $\mathrm{Nrx}$ C-terminal fragments is associated with the inhibition of presenilin/ Y-secretase (Saura et al., 2011). N-cadherin enhances APP dimerization, while its $C$-terminal fragment accelerates $A \beta$ and causes synapse damage (Asada-Utsugi et al., 2011; Andreyeva et al., 2012). $\beta$-catenin mediates the structural changes associated with memory formation, suggesting a role in memory impairment (Maguschak and Ressler 2012). Nectin-1 serves as a substrate for PS/Y-secretase-like intramembrane proteolytic activity (Kim et al., 2002). Nectin-3 is also cleaved by intramembrane PS1/Y-secretase (Kim et al., 2011). Therefore, altered functions in various CAMs contribute to the pathogenesis of $A D$, although the precise underlying mechanism is still unknown.

\section{CAMs in other diseases}

CAMs are involved in many other neurological diseases beyond autism and AD. Schizophrenia, a mental disorder characterized by social withdrawal, paranoid delusions, and hallucinations, is associated with abnormal expression and function of CAMs. Embryonic NCAM dysfunction was linked with schizophrenia more than 20 years ago (Conrad and Scheibel 1987). Unlike the case of ASD patients (Plioplys et al., 1990), NCAM levels in serum and cerebrospinal fluid (CSF) increase in schizophrenic patients (Lyons et al., 1988; Poltorak et al., 1996). Interestingly, the hippocampus of schizophrenic patients shows a reduction of polysialylated NCAM (Barbeau et al., 1995). An increase in the cytosolic isoform of NCAM has also been observed in the hippocampus of schizophrenia patients (Vawter et al., 1998a). The ratio of NCAM/synaptic proteins is also changed in some cases, indicating alterations in mature/immature synapses. For example, an increase in the cytosolic NCAM/synaptophysin ratio was demonstrated in the hippocampus of schizophrenia patients (Vawter et al., 1999). Similarly, the cingulate cortex of schizophrenics also showed elevated NCAM/synaptophysin ratios (Honer et al., 1997). Much research in autism and mental retardation has implicated Nrxs in schizophrenia (Kirov et al., 2008). Whole-genome analysis conducted in 2008 identified a deletion in two affected siblings that disrupted Nrx1 (Kirov et al., 2008). Nrx1a exonic deletions have since been found in three patients with paranoid-type schizophrenia (Vrijenhoek et al., 2008). A later study of 2977 schizophrenia patients and 33746 controls examined Nrx1 for copy number variants (CNVs) and identified 66 deletions and 5 duplications in NRXN1 from the patients, confirming that Nrx1 is a risk gene for schizophrenia (Rujescu et al., 2009). Bipolar (BP) disorder is another neuropsychiatric disorder that is related to CAMs. Recently, a genome-wide association scan of BP 1 disorder patients identified some single nucleotide polymorphisms (SNPs) in close vicinity to cadherin 7 (CDH7) (Sklar et al., 2008; Soronen et al., 2010). In 2010, PCDH9 was recognized as one of the target genes of $\beta$-catenin for schizophrenia and BP disorders (Pedrosa et al., 2010). Susceptibility to BP disorder was also found associated with FAT, a cadherin gene, in four independent cohorts (Blair et al., 2006).

The cytosolic NCAM isoform (cN-CAM) undergoes a tremendous reduction in BP disorder $(-140 \%)$ in hippocampal tissue (Vawter 2000). Quantitative Western blot analysis 
revealed that cytosolic NCAM protein and mRNA levels increased in the hippocampus and prefrontal cortex in $\mathrm{BP}$ disorder patients (Vawter et al., 1998b). Interestingly, NCAM infusion reduced astrocyte division, while BP disorder decreased glia numbers (Krushel et al., 1995; Ongür et al., 1998). Thus, different NCAM isoforms may play multiple roles in different brain regions in BP disorder patients.

Although only some superficial evidence that try to reveal the underlying mechanisms how CAMs are involved in neurological diseases pathogenesis can be observed, two points are seemed quite certain: on one hand, many CAMs could contribute in one neurological disease; on the other hand, one altered CAM could result in several neurological disorders, both in either separate or in cooperative way. Thus no 'leading' protein represents a common pathway for each of the neurological diseases, it is more likely that 'many hands make light work' in nature. Therefore more investments are required to deepen our understanding of the mechanisms of the molecular regulation of synapses.

\section{SUMMARY}

Neurons communicate via synaptic connection mostly mediated by precisely-controlled intercellular interactions. CAMs are involved in all stages of synapse formation and stabilization, providing 'bridges' between pre- and post-synaptic sites. At present, mounting evidence clearly indicates that no single pair of CAMs is necessary or sufficient for the organization of synapse developments from initiation to maturation, indicating overlapping or redundant functions of CAMs. The diversity of the isoforms and functions of CAMs may contribute to the complexity of neuronal network. Abnormalities in CAMs often cause neurological diseases.

The involvement of CAMs in synaptogenesis and synaptic connection is now well accepted. However, it remains unclear that actually how many and which proteins are involved in the process of synaptogenesis, how these distinct CAMs contribute to the specific synapse sybtypes and functions and how the CAMs cooperate together. At present, in view of the large variety of synapses in the brain, the number of known CAMs is surprisingly low. It is natural to speculate that more proteins are involved in this process, perhaps even some 'old' molecules with recognized activities in other aspects of functions. For instance, SNAP25, one component of the SNARE complex required for synaptic exocytosis, regulates dendritic spine maturation and function through its expression level (Tomasoni et al., 2013). Complexin2, a key regulator of neurotransmitter release, also has a role in synaptogenesis (Lee et al., 2005). A deficit in Munc18 or Munc13 also reduces the outgrowth speed of neurite at the early stage of development (Broeke et al., 2010). Thrombospondins (TSPs), proteins known in angiogenesis and many immune regulations, promote neuronal synaptogenesis in vitro and in vivo (Christopherson et al., 2005). Although these proteins may interfere with CAM- mediated intercellular interactions or receptors trafficking rather than function in synaptogenesis directly and make the cases even more complicate. Together, determining the proteins that take part in synapse developments is one of the highest priorities in neuroscience research. Clearly, largescale screening with better technology or improved design might be an inspiring way to uncover additional new CAMs, or identify already known synaptic proteins such as CAMs, to provide a better understanding of the physiology and pathology occurring during synapse development.

\section{ACKNOWLEDGEMENTS}

We sincerely apologize to the many authors whose works were not cited in this review due to space considerations. This work was supported by the National Basic Research Program (973 Program) (Nos. 2011CB809102 and 2014CB942804 to ZC), and the National Natural Science Foundation of China (Grant Nos. 31222025, 31171025 to ZC and 31300892 to YX), and Program for New Century Excellent Talents in University of Ministry of Education of China (ZC), and the Project Sponsored by the Scientific Research Foundation for the Returned Overseas Chinese Scholars, State Education Ministry (ZC).

\section{ABBREVIATIONS}

AChR, acetylcholine receptor; AD, Alzheimer's disease; CAMs, cell adhesion molecules; CNTN, contactins; Cdk5, cyclin-dependent kinase 5; FGF, fibroblast growth factor; GKAP, guanylate kinaseassociated protein; KO, knockout; LAR-RPTPs, leukocyte antigenrelated receptor protein tyrosine phosphatases; LRRTMs, leucinerich repeat transmembrane neuronal proteins; LTD, long-term depression; MAPK, mitogen-activated protein kinase; NCAM, neural cell adhesion molecule; NLs, neuroligins; Nrxs, neurexins; PSD, post-synaptic density; SAM, sterile alpha motif; SALMs, synaptic adhesion-like molecules; SynCAM, synaptic cell adhesion molecules.

\section{COMPLIANCE WITH ETHICS GUIDELINES}

The authors declare that they have no conflict of interest. This article does not contain any studies with human or animal subjects performed by the any of the authors.

\section{OPEN ACCESS}

This article is distributed under the terms of the Creative Commons Attribution License which permits any use, distribution, and reproduction in any medium, provided the original author(s) and the source are credited.

\section{REFERENCES}

Aiga M, Levinson JN, Bamji SX (2011) N-cadherin and neuroligins cooperate to regulate synapse formation in hippocampal cultures. J Biol Chem 286:851-858

Akert K, Streit P, Sandri C, Livingston R, Moor H (1972) Synapses as indicators of elevated and depressed activity. An electron 
microscopic analysis. Schweiz Arch Neurol Neurochir Psychiatr 111:227-236

Andreyeva A, Nieweg K, Horstmann K, Klapper S, Müller-Schiffmann A, Korth C, Gottmann K (2012) C-terminal fragment of $\mathrm{N}$-cadherin accelerates synapse destabilization by amyloid- $\beta$. Brain 135:2140-2154

Ango F, di Cristo G, Higashiyama H, Bennett V, Wu P, Huang ZJ (2004) Ankyrin-based subcellular gradient of neurofascin, an immunoglobulin family protein, directs GABAergic innervation at purkinje axon initial segment. Cell 119:257-272

Ango F, Wu C, Van der Want JJ, Wu P, Schachner M, Huang ZJ (2008) Bergmann glia and the recognition molecule CHL1 organize GABAergic axons and direct innervation of Purkinje cell dendrites. PLoS Biol 6:e103

Antion MD, Christie LA, Bond AM, Dalva MB, Contractor A (2010) Ephrin-B3 regulates glutamate receptor signaling at hippocampal synapses. Mol Cell Neurosci 45:378-388

Aoto J, Ting P, Maghsoodi B, Xu N, Henkemeyer M, Chen L (2007) Post-synaptic ephrinB3 promotes shaft glutamatergic synapse formation. J Neurosci 27:7508-7519

Aoto J, Martinelli DC, Malenka RC, Tabuchi K, Südhof TC (2013) Pre-synaptic neurexin-3 alternative splicing trans-synaptically controls post-synaptic AMPA receptor trafficking. Cell 154:75-88

Araç D, Boucard AA, Ozkan E, Strop P, Newell E, Südhof TC, Brunger AT (2007) Structures of neuroligin-1 and the neuroligin-1/ neurexin-1 beta complex reveal specific protein-protein and protein-Ca2 + interactions. Neuron 56:992-1003

Armstrong JN, Saganich MJ, Xu NJ, Henkemeyer M, Heinemann SF, Contractor A (2006) B-ephrin reverse signaling is required for NMDA-independent long-term potentiation of mossy fibers in the hippocampus. J Neurosci 26:3474-3481

Asada-Utsugi M, Uemura K, Noda Y, Kuzuya A, Maesako M, Ando K, Kubota M, Watanabe K, Takahashi M, Kihara T, Shimohama S, Takahashi R, Berezovska O, Kinoshita A (2011) N-cadherin enhances APP dimerization at the extracellular domain and modulates $A \beta$ production. J Neurochem 119:354-363

Bamji SX, Shimazu K, Kimes N, Huelsken J, Birchmeier W, Lu B, Reichardt LF (2003) Role of beta-catenin in synaptic vesicle localization and pre-synaptic assembly. Neuron 40:719-731

Barbeau D, Liang JJ, Robitalille Y, Quirion R, Srivastava LK (1995) Decreased expression of the embryonic form of the neural cell adhesion molecule in schizophrenic brains. Proc Natl Acad Sci USA 92:2785-2789

Barrow SL, Constable JR, Clark E, El-Sabeawy F, McAllister AK, Washbourne P (2009) Neuroligin1: a cell adhesion molecule that recruits PSD-95 and NMDA receptors by distinct mechanisms during synaptogenesis. Neural Dev 4:17

Bateman A, Jouet M, MacFarlane J, Du JS, Kenwrick S, Chothia C (1996) Outline structure of the human L1 cell adhesion molecule and the sites where mutations cause neurological disorders. EMBO J 15:6050-6059

Baudouin S, Scheiffele P (2010) SnapShot: Neuroligin-neurexin complexes. Cell 141(908):908

Bayés A, van de Lagemaat LN, Collins MO, Croning MD, Whittle IR, Choudhary JS, Grant SG (2011) Characterization of the proteome, diseases and evolution of the human post-synaptic density. Nat Neurosci 14:19-21
Benson DL, Tanaka H (1998) N-cadherin redistribution during synaptogenesis in hippocampal neurons. J Neurosci 18:68926904

Berninghausen O, Rahman MA, Silva JP, Davletov B, Hopkins C, Ushkaryov YA (2007) Neurexin lbeta and neuroligin are localized on opposite membranes in mature central synapses. J Neurochem 103:1855-1863

Biederer T, Sara Y, Mozhayeva M, Atasoy D, Liu X, Kavalali ET, Südhof TC (2002) SynCAM, a synaptic adhesion molecule that drives synapse assembly. Science 297:1525-1531

Blair IP, Chetcuti AF, Badenhop RF, Scimone A, Moses MJ, Adams LJ, Craddock N, Green E, Kirov G, Owen MJ, Kwok JB, Donald JA, Mitchell PB, Schofield PR (2006) Positional cloning, association analysis and expression studies provide convergent evidence that the cadherin gene FAT contains a bipolar disorder susceptibility allele. Mol Psychiatry 11:372-383

Bloom FE, Aghajanian GK (1966) Cytochemistry of synapses: selective staining for electron microscopy. Science 154:15751577

Borg JP, Lõpez-Figueroa MO, de Taddèo-Borg M, Kroon DE, Turner RS, Watson SJ, Margolis B (1999) Molecular analysis of the X11$\mathrm{mLin}-2 / C A S K$ complex in brain. J Neurosci 19:1307-1316

Bot N, Schweizer C, Ben Halima S, Fraering PC (2011) Processing of the synaptic cell adhesion molecule neurexin-3beta by Alzheimer disease alpha- and gamma-secretases. J Biol Chem 286:2762-2773

Boucard AA, Chubykin AA, Comoletti D, Taylor P, Südhof TC (2005) A splice code for trans-synaptic cell adhesion mediated by binding of neuroligin 1 to alpha- and beta-neurexins. Neuron 48:229-236

Bourgin C, Murai KK, Richter M, Pasquale EB (2007) The EphA4 receptor regulates dendritic spine remodeling by affecting beta1integrin signaling pathways. J Cell Biol 178:1295-1307

Bouzioukh F, Wilkinson GA, Adelmann G, Frotscher M, Stein V, Klein R (2007) Tyrosine phosphorylation sites in ephrinB2 are required for hippocampal long-term potentiation but not long-term depression. J Neurosci 7:1279-1288

Bozdagi O, Wang XB, Nikitczuk JS, Anderson TR, Bloss EB, Radice GL, Zhou Q, Benson DL, Huntley GW (2010) Persistence of coordinated long-term potentiation and dendritic spine enlargement at mature hippocampal CA1 synapses requires $\mathrm{N}$-cadherin. J Neurosci 30:9984-9989

Brigidi GS, Bamji SX (2011) Cadherin-catenin adhesion complexes at the synapse. Curr Opin Neurobiol 21:208-214

Broeke JH, Roelandse M, Luteijn MJ, Boiko T, Matus A, Toonen RF, Verhage $M$ (2010) Munc18 and Munc13 regulate early neurite outgrowth. Biol Cell 102:479-488

Brookmeyer R, Johnson E, Ziegler-Graham K, Arrighi HM (2007) Forecasting the global burden of Alzheimer's disease. Alzheimers Dement 3:186-191

Bukalo O, Dityatev A (2012) Synaptic cell adhesion molecules. Adv Exp Med Biol 970:97-128

Bukalo O, Fentrop N, Lee AY, Salmen B, Law JW, Wotjak CT, Schweizer M, Dityatev A, Schachner M (2004) Conditional ablation of the neural cell adhesion molecule reduces precision of spatial learning, long-term potentiation, and depression in the CA1 subfield of mouse hippocampus. J Neurosci 24:1565-1577 
Buttiglione M, Revest JM, Rougon G, Faivre-Sarrailh C (1996) F3 neuronal adhesion molecule controls outgrowth and fasciculation of cerebellar granule cell neurites: a cell-type-specific effect mediated by the Ig-like domains. Mol Cell Neurosci 8:53-69

Butz S, Okamoto M, Südhof TC (1998) A tripartite protein complex with the potential to couple synaptic vesicle exocytosis to cell adhesion in brain. Cell 94:773-782

Carrasquillo MM, Zou F, Pankratz VS, Wilcox SL, Ma L, Walker LP, Younkin SG, Younkin CS, Younkin LH, Bisceglio GD, ErtekinTaner N, Crook JE, Dickson DW, Petersen RC, Graff-Radford NR, Younkin SG (2009) Genetic variation in PCDH11X is associated with susceptibility to late-onset Alzheimer's disease. Nat Genet 41:192-198

Chagnon MJ, Uetani N, Tremblay ML (2004) Functional significance of the LAR receptor protein tyrosine phosphatase family in development and diseases. Biochem Cell Biol 82:664-675

Chan SA, Polo-Parada L, Landmesser LT, Smith C (2005) Adrenal chromaffin cells exhibit impaired granule trafficking in NCAM knockout mice. J Neurophysiol 94:1037-1047

Chang S, Rathjen FG, Raper JA (1987) Extension of neurites on axons is impaired by antibodies against specific neural cell surface glycoproteins. J Cell Biol 104:355-662

Chapman NH, Estes A, Munson J, Bernier R, Webb SJ, Rothstein JH, Minshew NJ, Dawson G, Schellenberg GD, Wijsman EM (2011) Genome-scan for IQ discrepancy in autism: evidence for loci on chromosomes 10 and 16. Hum Genet 129:59-70

Chattopadhyaya B, Baho E, Huang ZJ, Schachner M, Di Cristo G (2013) Neural cell adhesion molecule-mediated Fyn activation promotes GABAergic synapse maturation in postnatal mouse cortex. J Neurosci 33:5957-5968

Chavis P, Westbrook G (2001) Integrins mediate functional pre- and post-synaptic maturation at a hippocampal synapse. Nature 411:317-321

Chen BM, Grinnell AD (1995) Integrins and modulation of transmitter release from motor nerve terminals by stretch. Science 269:1578-1580

Chen X, Liu H, Shim AH, Focia PJ, He X (2008) Structural basis for synaptic adhesion mediated by neuroligin-neurexin interactions. Nat Struct Mol Biol 15:50-56

Chen F, Venugopal V, Murray B, Rudenko G (2011) The structure of neurexin $1 \alpha$ reveals features promoting a role as synaptic organizer. Structure 19:779-789

Chen Y, Fu AK, Ip NY (2012) Eph receptors at synapses: implications in neurodegenerative diseases. Cell Signal 24:606-611

Cheng D, Hoogenraad CC, Rush J, Ramm E, Schlager MA, Duong DM, Xu P, Wijayawardana SR, Hanfelt J, Nakagawa T, Sheng M, Peng J (2006) Relative and absolute quantification of postsynaptic density proteome isolated from rat forebrain and cerebellum. Mol Cell Proteomics 5:1158-1170

Chih B, Afridi SK, Clark L, Scheiffele P (2004) Disorder-associated mutations lead to functional inactivation of neuroligins. Hum Mol Genet 13:1471-1477

Chih B, Engelman H, Scheiffele P (2005) Control of excitatory and inhibitory synapse formation by neuroligins. Science 307:1324-1328

Chih B, Gollan L, Scheiffele P (2006) Alternative splicing controls selective trans-synaptic interactions of the neuroligin-neurexin complex. Neuron 51:171-178
Christopherson KS, Ullian EM, Stokes CC, Mullowney CE, Hell JW, Agah A, Lawler J, Mosher DF, Bornstein P, Barres BA (2005) Thrombospondins are astrocyte-secreted proteins that promote CNS synaptogenesis. Cell 120:421-433

Chubykin AA, Atasoy D, Etherton MR, Brose N, Kavalali ET, Gibson JR, Südhof TC (2007) Activity-dependent validation of excitatory versus inhibitory synapses by neuroligin-1 versus neuroligin-2. Neuron 54:919-931

Cingolani LA, Thalhammer A, Yu LM, Catalano M, Ramos T, Colicos MA, Goda Y (2008) Activity-dependent regulation of synaptic AMPA receptor composition and abundance by beta3 integrins. Neuron 58:749-762

Cissé M, Halabisky B, Harris J, Devidze N, Dubal DB, Sun B, Orr A, Lotz G, Kim DH, Hamto P, Ho K, Yu GQ, Mucke L (2011) Reversing EphB2 depletion rescues cognitive functions in Alzheimer model. Nature 469:47-52

Clifford MA, Kanwal JK, Dzakpasu R, Donoghue MJ (2011) EphA4 expression promotes network activity and spine maturation in cortical neuronal cultures. Neural Dev 6:21

Collins MO, Husi H, Yu L, Brandon JM, Anderson CN, Blackstock WP, Choudhary JS, Grant SG (2006) Molecular characterization and comparison of the components and multiprotein complexes in the post-synaptic proteome. J Neurochem 97:16-23

Comoletti D, De Jaco A, Jennings LL, Flynn RE, Gaietta G, Tsigelny I, Ellisman MH, Taylor P (2004) The Arg451Cys-neuroligin-3 mutation associated with autism reveals a defect in protein processing. J Neurosci 24:4889-4893

Comoletti D, Flynn RE, Boucard AA, Demeler B, Schirf V, Shi J, Jennings LL, Newlin HR, Südhof TC, Taylor P (2006) Gene selection, alternative splicing, and post-translational processing regulate neuroligin selectivity for beta-neurexins. Biochemistry 45:12816-12827

Conrad AJ, Scheibel AB (1987) Schizophrenia and the hippocampus: the embryological hypothesis extended. Schizophr Bull 13:577-587

Contractor A, Rogers C, Maron C, Henkemeyer M, Swanson GT, Heinemann SF (2002) Trans-synaptic Eph receptor-ephrin signaling in hippocampal mossy fiber LTP. Science 296:1864-1869

Cotman CW, Taylor D (1972) Isolation and structural studies on synaptic complexes from rat brain. J Cell Biol 55:696-711

Cottrell CE, Bir N, Varga E, Alvarez CE, Bouyain S, Zernzach R, Thrush DL, Evans J, Trimarchi M, Butter EM, Cunningham D, Gastier-Foster JM, McBride KL, Herman GE (2011) Contactin 4 as an autism susceptibility locus. Autism Res 4:189-199

Craig AM, Kang Y (2007) Neurexin-neuroligin signaling in synapse development. Curr Opin Neurobiol 17:43-52

Daar IO (2012) Non-SH2/PDZ reverse signaling by ephrins. Semin Cell Dev Biol 23:65-74

Dalva MB, McClelland AC, Kayser MS (2007) Cell adhesion molecules: signalling functions at the synapse. Nat Rev Neurosci 8:206-220

Davy A, Soriano P (2005) Ephrin signaling in vivo: look both ways. Dev Dyn 232:1-10

De Angelis E, MacFarlane J, Du JS, Yeo G, Hicks R, Rathjen FG, Kenwrick S, Brümmendorf T (1999) Pathological missense mutations of neural cell adhesion molecule L1 affect homophilic and heterophilic binding activities. EMBO J 18:4744-4753 
De Strooper B (2003) Aph-1, Pen-2, and Nicastrin with Presenilin generate an active gamma-Secretase complex. Neuron 38:9-12 de Wit J, Sylwestrak E, O'Sullivan ML, Otto S, Tiglio K, Savas JN, Yates JR 3rd, Comoletti D, Taylor P, Ghosh A (2009) LRRTM2 interacts with Neurexin1 and regulates excitatory synapse formation. Neuron 64:799-806

Deininger K, Eder M, Kramer ER, Zieglgänsberger W, Dodt HU, Dornmair K, Colicelli J, Klein R (2008) The Rab5 guanylate exchange factor Rin1 regulates endocytosis of the EphA4 receptor in mature excitatory neurons. Proc Natl Acad Sci USA 105:12539-12544

Di Luca M, Baker M, Corradetti R, Kettenmann H, Mendlewicz J, Olesen J, Ragan I, Westphal M (2011) Consensus document on European brain research. Eur J Neurosci 33:768-818

Dickinson BA, Jo J, Seok H, Son GH, Whitcomb DJ, Davies $\mathrm{CH}$, Sheng M, Collingridge GL, Cho K (2009) A novel mechanism of hippocampal LTD involving muscarinic receptor-triggered interactions between AMPARs, GRIP and liprin-alpha. Mol Brain 2:18

Dityatev A, Dityateva G, Schachner M (2000) Synaptic strength as a function of post- versus presynaptic expression of the neural cell adhesion molecule NCAM. Neuron 26:207-217

Dosemeci A, Tao-Cheng JH, Vinade L, Jaffe H (2006) Preparation of post-synaptic density fraction from hippocampal slices and proteomic analysis. Biochem Biophys Res Commun 339:687694

Dunah AW, Hueske E, Wyszynski M, Hoogenraad CC, Jaworski J, Pak DT, Simonetta A, Liu G, Sheng M (2005) LAR receptor protein tyrosine phosphatases in the development and maintenance of excitatory synapses. Nat Neurosci 8:458-467

Egea J, Klein R (2007) Bidirectional Eph-ephrin signaling during axon guidance. Trends Cell Biol 17:230-238

Fannon AM, Colman DR (1996) A model for central synaptic junctional complex formation based on the differential adhesive specificities of the cadherins. Neuron 17:423-434

Fantin M, van der Kooij MA, Grosse J, Krummenacher C, Sandi C (2013) A key role for nectin-1 in the ventral hippocampus in contextual fear memory. PLoS One 8:e56897

Feng J, Schroer R, Yan J, Song W, Yang C, Bockholt A, Cook EH Jr, Skinner C, Schwartz CE, Sommer SS (2006) High frequency of neurexin 1 beta signal peptide structural variants in patients with autism. Neurosci Lett 409:10-13

Fernandez T, Morgan T, Davis N, Klin A, Morris A, Farhi A, Lifton RP, State MW (2004) Disruption of contactin 4 (CNTN4) results in developmental delay and other features of $3 p$ deletion syndrome. Am J Hum Genet 74:1286-1293

Fernández E, Collins MO, Uren RT, Kopanitsa MV, Komiyama NH, Croning MD, Zografos L, Armstrong JD, Choudhary JS, Grant SG (2009) Targeted tandem affinity purification of PSD-95 recovers core post-synaptic complexes and schizophrenia susceptibility proteins. Mol Syst Biol 5:269

Filosa A, Paixão S, Honsek SD, Carmona MA, Becker L, Feddersen B, Gaitanos L, Rudhard Y, Schoepfer R, Klopstock T, Kullander K, Rose CR, Pasquale EB, Klein R (2009) Neuron-glia communication via EphA4/ephrin-A3 modulates LTP through glial glutamate transport. Nat Neurosci 12:1285-1292

Fischer G, Künemund V, Schachner M (1986) Neurite outgrowth patterns in cerebellar microexplant cultures are affected by antibodies to the cell surface glycoprotein L1. J Neurosci 6:605612

Fogel AI, Akins MR, Krupp AJ, Stagi M, Stein V, Biederer T (2007) SynCAMs organize synapses through heterophilic adhesion. J Neurosci 27:12516-12530

Fogel Al, Stagi M, Perez de Arce K, Biederer T (2011) Lateral assembly of the immunoglobulin protein SynCAM 1 controls its adhesive function and instructs synapse formation. EMBO J 30:4728-4738

Fu WY, Chen Y, Sahin M, Zhao XS, Shi L, Bikoff JB, Lai KO, Yung WH, Fu AK, Greenberg ME, Ip NY (2007) Cdk5 regulates EphA4mediated dendritic spine retraction through an ephexin1-dependent mechanism. Nat Neurosci 10:67-76

Fu AK, Hung KW, Fu WY, Shen C, Chen Y, Xia J, Lai KO, Ip NY (2011) APC(Cdh1) mediates EphA4-dependent downregulation of AMPA receptors in homeostatic plasticity. Nat Neurosci 14:181-189

Giagtzoglou N, Ly CV, Bellen HJ (2009) Cell adhesion, the backbone of the synapse: "vertebrate" and "invertebrate" perspectives. Cold Spring Harb Perspect Biol 1:a003079

Gil OD, Zhang L, Chen S, Ren YQ, Pimenta A, Zanazzi G, Hillman D, Levitt P, Salzer JL (2002) Complementary expression and heterophilic interactions between IgLON family members neurotrimin and LAMP. J Neurobiol 51:190-204

Giza JI, Jung Y, Jeffrey RA, Neugebauer NM, Picciotto MR, Biederer T (2013) The synaptic adhesion molecule SynCAM 1 contributes to cocaine effects on synapse structure and psychostimulant behavior. Neuropsychopharmacology 38:628-638

Gokce O, Südhof TC (2013) Membrane-tethered monomeric neurexin LNS-domain triggers synapse formation. J Neurosci 33:14617-14628

Gray EG (1959) Electron microscopy of synaptic contacts on dendrite spines of the cerebral cortex. Nature 183:1592-1593

Grunwald IC, Korte M, Wolfer D, Wilkinson GA, Unsicker K, Lipp HP, Bonhoeffer T, Klein R (2001) Kinase-independent requirement of EphB2 receptors in hippocampal synaptic plasticity. Neuron 32:1027-1040

Grunwald IC, Korte M, Adelmann G, Plueck A, Kullander K, Adams $\mathrm{RH}$, Frotscher M, Bonhoeffer T, Klein R (2004) Hippocampal plasticity requires post-synaptic ephrinBs. Nat Neurosci 7:33-40

Guan H, Maness PF (2010) Perisomatic GABAergic innervation in prefrontal cortex is regulated by ankyrin interaction with the L1 cell adhesion molecule. Cereb Cortex 20:2684-2693

Guo H, Xun G, Peng Y, Xiang X, Xiong Z, Zhang L, He Y, Xu X, Liu Y, Lu L, Long Z, Pan Q, Hu Z, Zhao J, Xia K (2012) Disruption of Contactin 4 in two subjects with autism in Chinese population. Gene 505:201-205

Hahn CG, Banerjee A, Macdonald ML, Cho DS, Kamins J, Nie Z, Borgmann-Winter KE, Grosser T, Pizarro A, Ciccimaro E, Arnold SE, Wang HY, Blair IA (2009) The post-synaptic density of human postmortem brain tissues: an experimental study paradigm for neuropsychiatric illnesses. PLoS One 4:e5251

Harburger DS, Calderwood DA (2009) Integrin signalling at a glance. J Cell Sci 122:159-163

Hashimoto T, Yamada M, Maekawa S, Nakashima T, Miyata S (2008) IgLON cell adhesion molecule Kilon is a crucial modulator for synapse number in hippocampal neurons. Brain Res 1224: $1-11$ 
Hashimoto T, Maekawa S, Miyata S (2009) IgLON cell adhesion molecules regulate synaptogenesis in hippocampal neurons. Cell Biochem Funct 27:496-498

Heine M, Thoumine O, Mondin M, Tessier B, Giannone G, Choquet D (2008) Activity-independent and subunit-specific recruitment of functional AMPA receptors at neurexin/neuroligin contacts. Proc Natl Acad Sci USA 105:20947-20952

Henderson JT, Georgiou J, Jia Z, Robertson J, Elowe S, Roder JC, Pawson T (2001) The receptor tyrosine kinase EphB2 regulates NMDA-dependent synaptic function. Neuron 32:1041-1056

Henkemeyer M, Itkis OS, Ngo M, Hickmott PW, Ethell IM (2003) Multiple EphB receptor tyrosine kinases shape dendritic spines in the hippocampus. J Cell Biol 163:1313-1326

Herron LR, Hill M, Davey F, Gunn-Moore FJ (2009) The intracellular interactions of the $\mathrm{L} 1$ family of cell adhesion molecules. Biochem J 419:519-531

Himanen JP (2012) Ectodomain structures of Eph receptors. Semin Cell Dev Biol 23:35-42

Hirano S, Takeichi M (2012) Cadherins in brain morphogenesis and wiring. Physiol Rev 92:597-634

Honda T, Sakisaka T, Yamada T, Kumazawa N, Hoshino T, Kajita M, Kayahara T, Ishizaki H, Tanaka-Okamoto M, Mizoguchi A, Manabe T, Miyoshi J, Takai Y (2006) Involvement of nectins in the formation of puncta adherentia junctions and the mossy fiber trajectory in the mouse hippocampus. Mol Cell Neurosci 31:315-325

Honer WG, Falkai P, Young C, Wang T, Xie J, Bonner J, Hu L, Boulianne GL, Luo Z, Trimble WS (1997) Cingulate cortex synaptic terminal proteins and neural cell adhesion molecule in schizophrenia. Neuroscience 78:99-110

Horn KE, Xu B, Gobert D, Hamam BN, Thompson KM, Wu CL, Bouchard JF, Uetani N, Racine RJ, Tremblay ML, Ruthazer ES, Chapman CA, Kennedy TE (2012) Receptor protein tyrosine phosphatase sigma regulates synapse structure, function and plasticity. J Neurochem 122:147-161

Hortsch M, Nagaraj K, Godenschwege TA (2009) The interaction between L1-type proteins and ankyrins-a master switch for L1type CAM function. Cell Mol Biol Lett 14:57-69

Hoy JL, Constable JR, Vicini S, Fu Z, Washbourne P (2009) SynCAM1 recruits NMDA receptors via protein 4.1B. Mol Cell Neurosci 42:466-483

Hruska M, Dalva MB (2012) Ephrin regulation of synapse formation, function and plasticity. Mol Cell Neurosci 50:35-44

Hynes RO (2002) Integrins: bidirectional, allosteric signaling machines. Cell 110:673-687

Ichtchenko K, Hata Y, Nguyen T, Ullrich B, Missler M, Moomaw C, Südhof TC (1995) Neuroligin 1: a splice site-specific ligand for beta-neurexins. Cell 81:435-443

Inoue E, Deguchi-Tawarada M, Togawa A, Matsui C, Arita K, Katahira-Tayama S, Sato T, Yamauchi E, Oda Y, Takai Y (2009) Synaptic activity prompts gamma-secretase-mediated cleavage of EphA4 and dendritic spine formation. J Cell Biol 185:551-564

Jamain S, Radyushkin K, Hammerschmidt K, Granon S, Boretius S, Varoqueaux F, Ramanantsoa N, Gallego J, Ronnenberg A, Winter D, Frahm J, Fischer J, Bourgeron T, Ehrenreich H, Brose N (2008) Reduced social interaction and ultrasonic communication in a mouse model of monogenic heritable autism. Proc Natl Acad Sci USA 105:1710-1715
Jedlicka P, Vnencak M, Krueger DD, Jungenitz T, Brose N, Schwarzacher SW (2013) Neuroligin-1 regulates excitatory synaptic transmission, LTP and EPSP-spike coupling in the dentate gyrus in vivo. Brain Struct Funct. doi:10.1007/s00429-013-0636-1

Jensen PH, Soroka V, Thomsen NK, Ralets I, Berezin V, Bock E, Poulsen FM (1999) Structure and interactions of NCAM modules 1 and 2, basic elements in neural cell adhesion. Nat Struct Biol 6:486-493

Jüngling $\mathrm{K}$, Eulenburg $\mathrm{V}$, Moore $\mathrm{R}$, Kemler R, Lessmann $\mathrm{V}$, Gottmann K (2006) N-cadherin transsynaptically regulates short-term plasticity at glutamatergic synapses in embryonic stem cell-derived neurons. J Neurosci 26:6968-6978

Kayser MS, McClelland AC, Hughes EG, Dalva MB (2006) Intracellular and trans-synaptic regulation of glutamatergic synaptogenesis by EphB receptors. J Neurosci 26:12152-12164

Kayser MS, Nolt MJ, Dalva MB (2008) EphB receptors couple dendritic filopodia motility to synapse formation. Neuron 59:56-69

Kim DY, Ingano LA, Kovacs DM (2002) Nectin-1alpha, an immunoglobulin-like receptor involved in the formation of synapses, is a substrate for presenilin/gamma-secretase-like cleavage. J Biol Chem 277:49976-49981

Kim S, Burette A, Chung HS, Kwon SK, Woo J, Lee HW, Kim K, Kim H, Weinberg RJ, Kim E (2006) NGL family PSD-95-interacting adhesion molecules regulate excitatory synapse formation. Nat Neurosci 9:1294-1301

Kim J, Chang A, Dudak A, Federoff HJ, Lim ST (2011) Characterization of nectin processing mediated by presenilin-dependent $\mathrm{\gamma}$ secretase. J Neurochem 119:945-956

Kirov G, Gumus D, Chen W, Norton N, Georgieva L, Sari M, O'Donovan MC, Erdogan F, Owen MJ, Ropers HH, Ullmann R (2008) Comparative genome hybridization suggests a role for NRXN1 and APBA2 in schizophrenia. Hum Mol Genet 17:458465

Klein R (2009) Bidirectional modulation of synaptic functions by Eph/ ephrin signaling. Nat Neurosci 12:15-20

Ko J, Kim S, Chung HS, Kim K, Han K, Kim H, Jun H, Kaang BK, Kim E (2006) SALM synaptic cell adhesion-like molecules regulate the differentiation of excitatory synapses. Neuron 50:233-245

Ko J, Fuccillo MV, Malenka RC, Südhof TC (2009) LRRTM2 functions as a neurexin ligand in promoting excitatory synapse formation. Neuron 64:791-798

Ko J, Soler-Llavina GJ, Fuccillo MV, Malenka RC, Südhof TC (2011) Neuroligins/LRRTMs prevent activity- and Ca2 +/calmodulindependent synapse elimination in cultured neurons. J Cell Biol 194:323-334

Kolkman MJ, Streijger F, Linkels M, Bloemen M, Heeren DJ, Hendriks WJ, Van der Zee CE (2004) Mice lacking leukocyte common antigen-related (LAR) protein tyrosine phosphatase domains demonstrate spatial learning impairment in the two-trial water maze and hyperactivity in multiple behavioural tests. Behav Brain Res 154:171-182

Kolkova K, Novitskaya V, Pedersen N, Berezin V, Bock E (2000) Neural cell adhesion molecule-stimulated neurite outgrowth depends on activation of protein kinase $\mathrm{C}$ and the Rasmitogen-activated protein kinase pathway. J Neurosci 20:22382246 
Krushel LA, Sporns O, Cunningham BA, Crossin KL, Edelman GM (1995) Neural cell adhesion molecule (N-CAM) inhibits astrocyte proliferation after injury to different regions of the adult rat brain. Proc Natl Acad Sci USA 92:4323-4327

Kullander K, Klein R (2002) Mechanisms and functions of Eph and ephrin signalling. Nat Rev Mol Cell Biol 3:475-486

Kwon SK, Woo J, Kim SY, Kim H, Kim E (2010) Trans-synaptic adhesions between netrin-G ligand-3 (NGL-3) and receptor tyrosine phosphatases LAR, protein-tyrosine phosphatase delta (PTPdelta), and PTPsigma via specific domains regulate excitatory synapse formation. J Biol Chem 285:13966-13978

Laumonnier F, Bonnet-Brilhault F, Gomot M, Blanc R, David A, Moizard MP, Raynaud M, Ronce N, Lemonnier E, Calvas $P$, Laudier B, Chelly J, Fryns JP, Ropers HH, Hamel BC, Andres C, Barthélémy C, Moraine C, Briault S (2004) X-linked mental retardation and autism are associated with a mutation in the NLGN4 gene, a member of the neuroligin family. Am J Hum Genet 74:552-557

Laurén J, Airaksinen MS, Saarma M, Timmusk T (2003) A novel gene family encoding leucine-rich repeat transmembrane proteins differentially expressed in the nervous system. Genomics 81:411-421

Law JW, Lee AY, Sun M, Nikonenko AG, Chung SK, Dityatev A, Schachner M, Morellini F (2003) Decreased anxiety, altered place learning, and increased CA1 basal excitatory synaptic transmission in mice with conditional ablation of the neural cell adhesion molecule L1. J Neurosci 23:10419-10432

Lee HJ, Song JY, Kim JW, Jin SY, Hong MS, Park JK, Chung JH, Shibata H, Fukumaki Y (2005) Association study of polymorphisms in synaptic vesicle-associated genes, SYN2 and CPLX2, with schizophrenia. Behav Brain Funct 1:15

Levinson JN, Chéry N, Huang K, Wong TP, Gerrow K, Kang R, Prange O, Wang YT, El-Husseini A (2005) Neuroligins mediate excitatory and inhibitory synapse formation: involvement of PSD95 and neurexin-1 beta in neuroligin-induced synaptic specificity. J Biol Chem 280:17312-17319

Lim ST, Lim KC, Giuliano RE, Federoff HJ (2008) (). Temporal and spatial localization of nectin-1 and l-afadin during synaptogenesis in hippocampal neurons. J Comp Neurol 507:1228-1244

Lindner J, Rathjen FG, Schachner M (1983) L1 mono- and polyclonal antibodies modify cell migration in early postnatal mouse cerebellum. Nature 305:427-430

Linhoff MW, Laurén J, Cassidy RM, Dobie FA, Takahashi H, Nygaard HB, Airaksinen MS, Strittmatter SM, Craig AM (2009) An unbiased expression screen for synaptogenic proteins identifies the LRRTM protein family as synaptic organizers. Neuron 61:734-749

Lisé MF, El-Husseini A (2006) The neuroligin and neurexin families: from structure to function at the synapse. Cell Mol Life Sci 63:1833-1849

Litterst C, Georgakopoulos A, Shioi J, Ghersi E, Wisniewski T, Wang R, Ludwig A, Robakis NK (2007) Ligand binding and calcium influx induce distinct ectodomain/gamma-secretase-processing pathways of EphB2 receptor. J Biol Chem 282:16155-16163

Little EB, Edelman GM, Cunningham BA (1998) Palmitoylation of the cytoplasmic domain of the neural cell adhesion molecule N-CAM serves as an anchor to cellular membranes. Cell Adhes Commun 6:415-430
Lodge AP, Howard MR, McNamee CJ, Moss DJ (2000) Colocalisation, heterophilic interactions and regulated expression of IgLON family proteins in the chick nervous system. Brain Res Mol Brain Res 82:84-94

Loers G, Schachner M (2007) Recognition molecules and neural repair. J Neurochem 101:865-882

Lyons F, Martin ML, Maguire C, Jackson A, Regan CM, Shelley RK (1988) The expression of an N-CAM serum fragment is positively correlated with severity of negative features in type II schizophrenia. Biol Psychiatry 23:769-775

Maguschak KA, Ressler KJ (2012) The dynamic role of beta-catenin in synaptic plasticity. Neuropharmacology 62:78-88

Mah W, Ko J, Nam J, Han K, Chung WS, Kim E (2010) Selected SALM (synaptic adhesion-like molecule) family proteins regulate synapse formation. J Neurosci 30:5559-5568

Majima T, Ogita $H$, Yamada T, Amano H, Togashi H, Sakisaka T, Tanaka-Okamoto M, Ishizaki H, Miyoshi J, Takai Y (2009) Involvement of afadin in the formation and remodeling of synapses in the hippocampus. Biochem Biophys Res Commun 385:539-544

Malhotra JD, Tsiotra P, Karagogeos D, Hortsch M (1998) Cisactivation of L1-mediated ankyrin recruitment by TAG-1 homophilic cell adhesion. J Biol Chem 273:33354-33359

Maness PF, Schachner M (2007) Neural recognition molecules of the immunoglobulin superfamily: signaling transducers of axon guidance and neuronal migration. Nat Neurosci 10:19-26

Margolis SS, Salogiannis J, Lipton DM, Mandel-Brehm C, Wills ZP, Mardinly AR, Hu L, Greer PL, Bikoff JB, Ho HY, Soskis MJ, Sahin M, Greenberg ME (2010) EphB-mediated degradation of the RhoA GEF Ephexin5 relieves a developmental brake on excitatory synapse formation. Cell 143:442-455

Matsui C, Inoue E, Kakita A, Arita K, Deguchi-Tawarada M, Togawa A, Yamada A, Takai Y, Takahashi H (2012) Involvement of the $\mathrm{Y}$ secretase-mediated EphA4 signaling pathway in synaptic pathogenesis of Alzheimer's disease. Brain Pathol 22:776-787

McGeachie AB, Skrzypiec AE, Cingolani LA, Letellier M, Pawlak R, Goda $Y$ (2012) $\beta 3$ integrin is dispensable for conditioned fear and hebbian forms of plasticity in the hippocampus. Eur $\mathrm{J}$ Neurosci 36:2461-2469

Mendez P, De Roo M, Poglia L, Klauser P, Muller D (2010) $\mathrm{N}$-cadherin mediates plasticity-induced long-term spine stabilization. J Cell Biol 189:589-600

Mercati O, Danckaert A, André-Leroux G, Bellinzoni M, Gouder L, Watanabe K, Shimoda Y, Grailhe R, De Chaumont F, Bourgeron T, Cloëz-Tayarani I (2013) Contactin 4, -5 and -6 differentially regulate neuritogenesis while they display identical PTPRG binding sites. Biol Open 2:324-334

Missler M, Fernandez-Chacon R, Südhof TC (1998) The making of neurexins. J Neurochem 71:1339-1347

Missler M, Zhang W, Rohlmann A, Kattenstroth G, Hammer RE, Gottmann K, Südhof TC (2003) Alpha-neurexins couple $\mathrm{Ca}+$ channels to synaptic vesicle exocytosis. Nature 423:939948

Miyata S, Matsumoto N, Taguchi K, Akagi A, lino T, Funatsu N, Maekawa S (2003) Biochemical and ultrastructural analyses of IgLON cell adhesion molecules, Kilon and OBCAM in the rat brain. Neuroscience 117:645-658 
Mizoguchi A, Nakanishi H, Kimura K, Matsubara K, Ozaki-Kuroda K, Katata T, Honda T, Kiyohara Y, Heo K, Higashi M, Tsutsumi T, Sonoda S, Ide C, Takai Y (2002) Nectin: an adhesion molecule involved in formation of synapses. J Cell Biol 156:555-565

Moos M, Tacke R, Scherer H, Teplow D, Früh K, Schachner M (1988) Neural adhesion molecule L1 as a member of the immunoglobulin superfamily with binding domains similar to fibronectin. Nature 334:701-703

Morellini F, Lepsveridze E, Kähler B, Dityatev A, Schachner M (2007) Reduced reactivity to novelty, impaired social behavior, and enhanced basal synaptic excitatory activity in perforant path projections to the dentate gyrus in young adult mice deficient in the neural cell adhesion molecule CHL1. Mol Cell Neurosci 34:121-136

Morrow EM, Yoo SY, Flavell SW, Kim TK, Lin Y, Hill RS, Mukaddes NM, Balkhy S, Gascon G, Hashmi A, Al-Saad S, Ware J, Joseph RM, Greenblatt R, Gleason D, Ertelt JA, Apse KA, Bodell A, Partlow JN, Barry B, Yao H, Markianos K, Ferland RJ, Greenberg ME, Walsh CA (2008) Identifying autism loci and genes by tracing recent shared ancestry. Science 321:218-223

Mortillo S, Elste A, Ge Y, Patil SB, Hsiao K, Huntley GW, Davis RL, Benson DL (2012) Compensatory redistribution of neuroligins and $\mathrm{N}$-cadherin following deletion of synaptic $\beta 1$-integrin. J Comp Neurol 520:2041-2052

Mukherjee K, Sharma M, Urlaub H, Bourenkov GP, Jahn R, Südhof TC, Wahl MC (2008) CASK Functions as a $\mathrm{Mg}^{2+}$-independent neurexin kinase. Cell 133:328-339

Muller D, Wang C, Skibo G, Toni N, Cremer H, Calaora V, Rougon G, Kiss JZ (1996) PSA-NCAM is required for activity-induced synaptic plasticity. Neuron 17:413-422

Murai KK, Misner D, Ranscht B (2002) Contactin supports synaptic plasticity associated with hippocampal long-term depression but not potentiation. Curr Biol 12:181-190

Murai KK, Nguyen LN, Koolpe M, McLennan R, Krull CE, Pasquale EB (2003) Targeting the EphA4 receptor in the nervous system with biologically active peptides. Mol Cell Neurosci 24:1000-1011

Nam Cl, Chen L (2005) Post-synaptic assembly induced by neurexin-neuroligin interaction and neurotransmitter. Proc Natl Acad Sci USA 102:6137-6142

Newschaffer CJ, Croen LA, Daniels J, Giarelli E, Grether JK, Levy SE, Mandell DS, Miller LA, Pinto-Martin J, Reaven J, Reynolds AM, Rice CE, Schendel D, Windham GC (2007) The epidemiology of autism spectrum disorders. Annu Rev Public Health 28:235-258

Nguyen T, Südhof TC (1997) Binding properties of neuroligin 1 and neurexin 1 beta reveal function as heterophilic cell adhesion molecules. J Biol Chem 272:26032-26039

Nikonenko AG, Sun M, Lepsveridze E, Apostolova I, Petrova I, Irintchev A, Dityatev A, Schachner M (2006) Enhanced perisomatic inhibition and impaired long-term potentiation in the CA1 region of juvenile CHL1-deficient mice. Eur J Neurosci 23:1839-1852

Ning L, Tian L, Smirnov S, Vihinen H, Llano O, Vick K, Davis RL, Rivera C, Gahmberg CG (2013) Interactions between ICAM-5 and $\beta 1$ integrins regulate neuronal synapse formation. J Cell Sci 126:77-89

Nuriya M, Huganir RL (2006) Regulation of AMPA receptor trafficking by N-cadherin. J Neurochem 97:652-661
Okuda T, Yu LM, Cingolani LA, Kemler R, Goda Y (2007) betaCatenin regulates excitatory post-synaptic strength at hippocampal synapses. Proc Natl Acad Sci USA 104:13479-13484

Ongür D, Drevets WC, Price JL (1998) Glial reduction in the subgenual prefrontal cortex in mood disorders. Proc Natl Acad Sci USA 95:13290-13295

Pagnamenta AT, Khan H, Walker S, Gerrelli D, Wing K, Bonaglia MC, Giorda R, Berney T, Mani E, Molteni M, Pinto D, Le Couteur A, Hallmayer J, Sutcliffe JS, Szatmari P, Paterson AD, Scherer SW, Vieland VJ, Monaco AP (2011) Rare familial 16q21 microdeletions under a linkage peak implicate cadherin 8 $(\mathrm{CDH} 8)$ in susceptibility to autism and learning disability. J Med Genet 48:48-54

Pedrosa E, Shah A, Tenore C, Capogna M, Villa C, Guo X, Zheng D, Lachman HM (2010) $\beta$-catenin promoter ChIP-chip reveals potential schizophrenia and bipolar disorder gene network. J Neurogenet 24:182-193

Peng J, Kim MJ, Cheng D, Duong DM, Gygi SP, Sheng M (2004) Semiquantitative proteomic analysis of rat forebrain post-synaptic density fractions by mass spectrometry. J Biol Chem 279:2100321011

Peng YR, Hou ZH, Yu X (2013) The kinase activity of EphA4 mediates homeostatic scaling-down of synaptic strength via activation of Cdk5. Neuropharmacology 65:232-243

Penzes P, Beeser A, Chernoff J, Schiller MR, Eipper BA, Mains RE, Huganir RL (2003) Rapid induction of dendritic spine morphogenesis by trans-synaptic ephrinB-EphB receptor activation of the Rho-GEF kalirin. Neuron 37:263-274

Perrin FE, Rathjen FG, Stoeckli ET (2001) Distinct subpopulations of sensory afferents require F11 or axonin-1 for growth to their target layers within the spinal cord of the chick. Neuron 30:707-723

Pfenninger KH (1971) The cytochemistry of synaptic densities. II. Proteinaceous components and mechanism of synaptic connectivity. J Ultrastruct Res 35:451-475

Pimenta AF, Reinoso BS, Levitt P (1996) Expression of the mRNAs encoding the limbic system-associated membrane protein (LAMP): II. Fetal rat brain. J Comp Neurol 375:289-302

Pinkstaff JK, Lynch G, Gall CM (1998) Localization and seizureregulation of integrin beta $1 \mathrm{mRNA}$ in adult rat brain. Brain Res Mol Brain Res 55:265-276

Plioplys AV, Hemmens SE, Regan CM (1990) Expression of a neural cell adhesion molecule serum fragment is depressed in autism. J Neuropsychiatry Clin Neurosci 2:413-417

Polo-Parada L, Bose CM, Landmesser LT (2001) Alterations in transmission, vesicle dynamics, and transmitter release machinery at NCAM-deficient neuromuscular junctions. Neuron 32:815828

Polo-Parada L, Plattner F, Bose C, Landmesser LT (2005) NCAM 180 acting via a conserved C-terminal domain and MLCK is essential for effective transmission with repetitive stimulation. Neuron 46:917-931

Poltorak M, Frye MA, Wright R, Hemperly JJ, George MS, Pazzaglia PJ, Jerrels SA, Post RM, Freed WJ (1996) Increased neural cell adhesion molecule in the CSF of patients with mood disorder. $J$ Neurochem 66:1532-1538

Pozo K, Cingolani LA, Bassani S, Laurent F, Passafaro M, Goda Y (2012) $\beta 3$ integrin interacts directly with GluA2 AMPA receptor 
subunit and regulates AMPA receptor expression in hippocampal neurons. Proc Natl Acad Sci USA 109:1323-1328

Pulido R, Serra-Pagès C, Tang M, Streuli M (1995) The LAR/PTP delta/PTP sigma subfamily of transmembrane protein-tyrosinephosphatases: multiple human LAR, PTP delta, and PTP sigma isoforms are expressed in a tissue-specific manner and associate with the LAR-interacting protein LIP.1. Proc Natl Acad Sci USA 92:11686-11690

Puzzo D, Bizzoca A, Privitera L, Furnari D, Giunta S, Girolamo F, Pinto M, Gennarini G, Palmeri A (2013) F3/Contactin promotes hippocampal neurogenesis, synaptic plasticity, and memory in adult mice. Hippocampus 23:1367-1382

Rafuse VF, Polo-Parada L, Landmesser LT (2000) Structural and functional alterations of neuromuscular junctions in NCAMdeficient mice. J Neurosci 20:6529-6539

Ramser EM, Wolters G, Dityateva G, Dityatev A, Schachner M, Tilling $T$ (2010) The 14-3-3 $\zeta$ protein binds to the cell adhesion molecule L1, promotes L1 phosphorylation by CKII and influences L1-dependent neurite outgrowth. PLoS One 5:e13462

Reissner C, Runkel F, Missler M (2013) Neurexins. Genome Biol 14:213-227

Ren Q, Bennett V (1998) Palmitoylation of neurofascin at a site in the membrane-spanning domain highly conserved among the L1 family of cell adhesion molecules. J Neurochem 70:1839-1849

Rentzos M, Michalopoulou M, Nikolaou C, Cambouri C, Rombos A, Dimitrakopoulos A, Vassilopoulos D (2005) The role of soluble intercellular adhesion molecules in neurodegenerative disorders. J Neurol Sci 228:129-135

Resnick M, Segall A, GR G, Lupowitz Z, Zisapel N (2008) Alternative splicing of neurexins: a role for neuronal polypyrimidine tract binding protein. Neurosci Lett 439:235-240

Reyes AA, Small SJ, Akeson R (1991) At least 27 alternatively spliced forms of the neural cell adhesion molecule mRNA are expressed during rat heart development. Mol Cell Biol 11:1654-1661

Richter M, Murai KK, Bourgin C, Pak DT, Pasquale EB (2007) The EphA4 receptor regulates neuronal morphology through SPARmediated inactivation of Rap GTPases. J Neurosci 27:1420514215

Rikitake Y, Mandai K, Takai Y (2012) The role of nectins in different types of cell-cell adhesion. J Cell Sci 125:3713-3722

Robbins EM, Krupp AJ, Perez de Arce K, Ghosh AK, Fogel Al, Boucard A, Südhof TC, Stein V, Biederer T (2010) SynCAM 1 adhesion dynamically regulates synapse number and impacts plasticity and learning. Neuron 68:894-906

Rujescu D, Ingason A, Cichon S, Pietiläinen OP, Barnes MR, Toulopoulou T, Picchioni M, Vassos E, Ettinger U, Bramon E, Murray $R$, Ruggeri $M$, Tosato $S$, Bonetto $C$, Steinberg $S$, Sigurdsson E, Sigmundsson T, Petursson H, Gylfason A, Olason PI, Hardarsson G, Jonsdottir GA, Gustafsson O, Fossdal R, Giegling I, Möller HJ, Hartmann AM, Hoffmann P, Crombie C, Fraser G, Walker N, Lonnqvist J, Suvisaari J, Tuulio-Henriksson A, Djurovic S, Melle I, Andreassen OA, Hansen T, Werge T, Kiemeney LA, Franke B, Veltman J, Buizer-Voskamp JE, Investigators GROUP, Sabatti C, Ophoff RA, Rietschel M, Nöthen MM, Stefansson K, Peltonen L, St Clair D, Stefansson H, Collier DA (2009) Disruption of the neurexin 1 gene is associated with schizophrenia. Hum Mol Genet 18:988-996
Saghatelyan AK, Nikonenko AG, Sun M, Rolf B, Putthoff P, Kutsche M, Bartsch U, Dityatev A, Schachner M (2004) Reduced GABAergic transmission and number of hippocampal perisomatic inhibitory synapses in juvenile mice deficient in the neural cell adhesion molecule L1. Mol Cell Neurosci 26:191-203

Saglietti L, Dequidt C, Kamieniarz K, Rousset MC, Valnegri P, Thoumine O, Beretta F, Fagni L, Choquet D, Sala C, Sheng M, Passafaro M (2007) Extracellular interactions between GluR2 and $\mathrm{N}$-cadherin in spine regulation. Neuron 54:461-477

Sakisaka T, Ikeda W, Ogita H, Fujita N, Takai Y (2007) The roles of nectins in cell adhesions: cooperation with other cell adhesion molecules and growth factor receptors. Curr Opin Cell Biol 19:593-602

Sakurai K, Toyoshima M, Ueda H, Matsubara K, Takeda Y, Karagogeos D, Shimoda Y, Watanabe K (2009) Contribution of the neural cell recognition molecule NB-3 to synapse formation between parallel fibers and Purkinje cells in mouse. Dev Neurobiol 69:811-824

Sakurai K, Toyoshima M, Takeda Y, Shimoda Y, Watanabe K (2010) Synaptic formation in subsets of glutamatergic terminals in the mouse hippocampal formation is affected by a deficiency in the neural cell recognition molecule NB-3. Neurosci Lett 473:102-106

Sanders SJ, Ercan-Sencicek AG, Hus V, Luo R, Murtha MT, MorenoDe-Luca D, Chu SH, Moreau MP, Gupta AR, Thomson SA, Mason CE, Bilguvar K, Celestino-Soper PB, Choi M, Crawford EL, Davis L, Wright NR, Dhodapkar RM, DiCola M, DiLullo NM, Fernandez TV, Fielding-Singh V, Fishman DO, Frahm S, Garagaloyan R, Goh GS, Kammela S, Klei L, Lowe JK, Lund SC, McGrew AD, Meyer KA, Moffat WJ, Murdoch JD, O'Roak BJ, Ober GT, Pottenger RS, Raubeson MJ, Song Y, Wang Q, Yaspan BL, Yu TW, Yurkiewicz IR, Beaudet AL, Cantor RM, Curland M, Grice DE, Günel M, Lifton RP, Mane SM, Martin DM, Shaw CA, Sheldon M, Tischfield JA, Walsh CA, Morrow EM, Ledbetter DH, Fombonne E, Lord C, Martin CL, Brooks AI, Sutcliffe JS, Cook EH Jr, Geschwind D, Roeder K, Devlin B, State MW (2011) Multiple recurrent de novo CNVs, including duplications of the $7 q 11.23$ Williams syndrome region, are strongly associated with autism. Neuron 70:863-885

Sanes JR, Yamagata M (2009) Many paths to synaptic specificity. Annu Rev Cell Dev Biol 25:161-195

Sara Y, Biederer T, Atasoy D, Chubykin A, Mozhayeva MG, Südhof TC, Kavalali ET (2005) Selective capability of SynCAM and neuroligin for functional synapse assembly. J Neurosci 25:260-270

Satoh K, Takeuchi M, Oda Y, Deguchi-Tawarada M, Sakamoto Y, Matsubara K, Nagasu T, Takai Y (2002) Identification of activityregulated proteins in the post-synaptic density fraction. Genes Cells 7:187-197

Saura CA, Servián-Morilla E, Scholl FG (2011) Presenilin/Y-secretase regulates neurexin processing at synapses. PLoS One 6: e19430

Schaefer AW, Kamiguchi H, Wong EV, Beach CM, Landreth G, Lemmon V (1999) Activation of the MAPK signal cascade by the neural cell adhesion molecule L1 requires L1 internalization. J Biol Chem 274:37965-37973

Scheiffele P, Fan J, Choih J, Fetter R, Serafini T (2000) Neuroligin expressed in nonneuronal cells triggers presynaptic development in contacting axons. Cell 101:657-669 
Seabold GK, Wang PY, Chang K, Wang CY, Wang YX, Petralia RS, Wenthold RJ (2008) The SALM family of adhesion-like molecules forms heteromeric and homomeric complexes. J Biol Chem 283:8395-8405

Seabold GK, Wang PY, Petralia RS, Chang K, Zhou A, McDermott MI, Wang YX, Milgram SL, Wenthold RJ (2012) Dileucine and PDZ-binding motifs mediate synaptic adhesion-like molecule 1 (SALM1) trafficking in hippocampal neurons. J Biol Chem 287:4470-4484

Siddiqui TJ, Tari PK, Connor SA, Zhang P, Dobie FA, She K, Kawabe H, Wang YT, Brose N, Craig AM (2013) An LRRTM4-HSPG complex mediates excitatory synapse development on dentate gyrus granule cells. Neuron 79:680-695

Simón AM, de Maturana RL, Ricobaraza A, Escribano L, Schiapparelli L, Cuadrado-Tejedor M, Pérez-Mediavilla A, Avila J, Del Río J, Frechilla D (2009) Early changes in hippocampal Eph receptors precede the onset of memory decline in mouse models of Alzheimer's disease. J Alzheimers Dis 17:773-786

Sindi IA, Tannenberg RK, Dodd PR (2014) A role for the neurexinneuroligin complex in Alzheimer's disease. Neurobiol Aging 35:746-756

Sklar P, Smoller JW, Fan J, Ferreira MA, Perlis RH, Chambert K, Nimgaonkar VL, McQueen MB, Faraone SV, Kirby A, de Bakker PI, Ogdie MN, Thase ME, Sachs GS, Todd-Brown K, Gabriel SB, Sougnez C, Gates C, Blumenstiel B, Defelice M, Ardlie KG, Franklin J, Muir WJ, McGhee KA, Macintyre DJ, McLean A, VanBeck M, McQuillin A, Bass NJ, Robinson M, Lawrence J, Anjorin A, Curtis D, Scolnick EM, Daly MJ, Blackwood DH, Gurling HM, Purcell SM (2008) Whole-genome association study of bipolar disorder. Mol Psychiatry 13:558-569

Soler-Llavina GJ, Fuccillo MV, Ko J, Südhof TC, Malenka RC (2011) The neurexin ligands, neuroligins and leucine-rich repeat transmembrane proteins, perform convergent and divergent synaptic functions in vivo. Proc Natl Acad Sci USA 108:16502-16509

Soler-Llavina GJ, Arstikaitis P, Morishita W, Ahmad M, Südhof TC, Malenka RC (2013) Leucine-rich repeat transmembrane proteins are essential for maintenance of long-term potentiation. Neuron 79:439-446

Soronen P, Ollila HM, Antila M, Silander K, Palo OM, Kieseppä T, Lönnqvist J, Peltonen L, Tuulio-Henriksson A, Partonen T, Paunio T (2010) Replication of GWAS of bipolar disorder: association of SNPs near $\mathrm{CDH} 7$ with bipolar disorder and visual processing. Mol Psychiatry 15:4-6

Soto F, Watkins KL, Johnson RE, Schottler F, Kerschensteiner D (2013) NGL-2 regulates pathway-specific neurite growth and lamination, synapse formation, and signal transmission in the retina. J Neurosci 33:11949-11959

Stan A, Pielarski KN, Brigadski T, Wittenmayer N, Fedorchenko O, Gohla A, Lessmann V, Dresbach T, Gottmann K (2010) Essential cooperation of $\mathrm{N}$-cadherin and neuroligin-1 in the transsynaptic control of vesicle accumulation. Proc Natl Acad Sci USA 107:11116-11121

Südhof TC (2008) Neuroligins and neurexins link synaptic function to cognitive disease. Nature 455:903-911

Sytnyk V, Leshchyns'ka I, Nikonenko AG, Schachner M (2006) NCAM promotes assembly and activity-dependent remodeling of the post-synaptic signaling complex. J Cell Biol 174:1071-1085
Tabuchi K, Südhof TC (2002) Structure and evolution of neurexin genes: insight into the mechanism of alternative splicing. Genomics 79:849-859

Tabuchi K, Blundell J, Etherton MR, Hammer RE, Liu X, Powell CM, Südhof TC (2007) A neuroligin-3 mutation implicated in autism increases inhibitory synaptic transmission in mice. Science 318:71-76

Takahashi H, Arstikaitis P, Prasad T, Bartlett TE, Wang YT, Murphy TH, Craig AM (2011) Post-synaptic TrkC and presynaptic PTPo function as a bidirectional excitatory synaptic organizing complex. Neuron 69:287-303

Takahashi H, Katayama K, Sohya K, Miyamoto H, Prasad T, Matsumoto Y, Ota M, Yasuda H, Tsumoto T, Aruga J, Craig AM (2012) Selective control of inhibitory synapse development by Slitrk3-PTPס trans-synaptic interaction. Nat Neurosci 15:389-398

Takai Y, Irie K, Shimizu K, Sakisaka T, Ikeda W (2003) Nectins and nectin-like molecules: roles in cell adhesion, migration, and polarization. Cancer Sci 94:655-667

Takeichi M (1988) The cadherins: cell-cell adhesion molecules controlling animal morphogenesis. Development 102:639-655

Takeichi M (2007) The cadherin superfamily in neuronal connections and interactions. Nat Rev Neurosci 8:11-20

Tallafuss A, Constable JR, Washbourne P (2010) Organization of central synapses by adhesion molecules. Eur J Neurosci 32:198-206

Taylor AM, Wu J, Tai HC, Schuman EM (2013) Axonal translation of $\beta$-catenin regulates synaptic vesicle dynamics. J Neurosci 33:5584-5589

Thomas LA, Akins MR, Biederer T (2008) Expression and adhesion profiles of SynCAM molecules indicate distinct neuronal functions. J Comp Neurol 510:47-67

Tolias KF, Bikoff JB, Kane CG, Tolias CS, Hu L, Greenberg ME (2007) The Rac1 guanine nucleotide exchange factor Tiam1 mediates EphB receptor-dependent dendritic spine development. Proc Natl Acad Sci USA 104:7265-7270

Tomasoni R, Repetto D, Morini R, Elia C, Gardoni F, Di Luca M, Turco E, Defilippi P, Matteoli M (2013) SNAP-25 regulates spine formation through post-synaptic binding to p140Cap. Nat Commun 4:2136

Trinidad JC, Thalhammer A, Specht CG, Lynn AJ, Baker PR, Schoepfer R, Burlingame AL (2008) Quantitative analysis of synaptic phosphorylation and protein expression. Mol Cell Proteomics 7:684-696

Tuvia S, Garver TD, Bennett V (1997) The phosphorylation state of the FIGQY tyrosine of neurofascin determines ankyrin-binding activity and patterns of cell segregation. Proc Natl Acad Sci USA 94:12957-12962

Uchida N, Honjo Y, Johnson KR, Wheelock MJ, Takeichi M (1996) The catenin/cadherin adhesion system is localized in synaptic junctions bordering transmitter release zones. J Cell Biol 135:767-779

Uemura M, Nakao S, Suzuki ST, Takeichi M, Hirano S (2007) OLProtocadherin is essential for growth of striatal axons and thalamocortical projections. Nat Neurosci 10:1151-1159

Uetani N, Kato K, Ogura H, Mizuno K, Kawano K, Mikoshiba K, Yakura H, Asano M, Iwakura Y (2000) Impaired learning with enhanced hippocampal long-term potentiation in PTPdelta-deficient mice. EMBO J 19:2775-2785 
Ullrich B, Ushkaryov YA, Südhof TC (1995) Cartography of neurexins: more than 1000 isoforms generated by alternative splicing and expressed in distinct subsets of neurons. Neuron 14:497507

van Daalen E, Kemner C, Verbeek NE, van der Zwaag B, Dijkhuizen $T$, Rump P, Houben R, van't Slot R, de Jonge MV, Staal WG, Beemer FA, Vorstman JA, Burbach JP, van Amstel HK, Hochstenbach R, Brilstra EH, Poot M (2011) Social Responsiveness Scale-aided analysis of the clinical impact of copy number variations in autism. Neurogenetics 12:315-323

Varoqueaux F, Jamain S, Brose N (2004) Neuroligin 2 is exclusively localized to inhibitory synapses. Eur J Cell Biol 83:449-456

Varoqueaux F, Aramuni G, Rawson RL, Mohrmann R, Missler M, Gottmann K, Zhang W, Südhof TC, Brose N (2006) Neuroligins determine synapse maturation and function. Neuron 51:741-754

Vawter MP (2000) Dysregulation of the neural cell adhesion molecule and neuropsychiatric disorders. Eur J Pharmacol 405:385-395

Vawter MP, Cannon-Spoor HE, Hemperly JJ, Hyde TM, VanderPutten DM, Kleinman JE, Freed WJ (1998a) Abnormal expression of cell recognition molecules in schizophrenia. Exp Neurol 149:424432

Vawter MP, Hemperly JJ, Hyde TM, Bachus SE, VanderPutten DM, Howard AL, Cannon-Spoor HE, McCoy MT, Webster MJ, Kleinman JE, Freed WJ (1998b) VASE-containing N-CAM isoforms are increased in the hippocampus in bipolar disorder but not schizophrenia. Exp Neurol 154:1-11

Vawter MP, Howard AL, Hyde TM, Kleinman JE, Freed WJ (1999) Alterations of hippocampal secreted N-CAM in bipolar disorder and synaptophysin in schizophrenia. Mol Psychiatry 4:467-475

Voikar V, Kulesskaya N, Laakso T, Lauren J, Strittmatter SM, Airaksinen MS (2013) LRRTM1-deficient mice show a rare phenotype of avoiding small enclosures-a tentative mouse model for claustrophobia-like behaviour. Behav Brain Res 238:69-78

Vrijenhoek T, Buizer-Voskamp JE, van der Stelt I, Strengman E, Genetic Risk and Outcome in Psychosis (GROUP) Consortium, Sabatti C, Geurts van Kessel A, Brunner HG, Ophoff RA, Veltman JA (2008) Recurrent CNVs disrupt three candidate genes in schizophrenia patients. Am J Hum Genet 83:504-510

Wang J, Luo ZG (2008) The role of Wnt/beta-catenin signaling in post-synaptic differentiation. Commun Integr Biol 1:158-160

Wang CY, Chang K, Petralia RS, Wang YX, Seabold GK, Wenthold RJ (2006) A novel family of adhesion-like molecules that interacts with the NMDA receptor. J Neurosci 26:2174-2183

Wang PY, Seabold GK, Wenthold RJ (2008) Synaptic adhesion-like molecules (SALMs) promote neurite outgrowth. Mol Cell Neurosci 39:83-94

Wang K, Zhang H, Ma D, Bucan M, Glessner JT, Abrahams BS, Salyakina D, Imielinski M, Bradfield JP, Sleiman PM, Kim CE, Hou C, Frackelton E, Chiavacci R, Takahashi N, Sakurai T, Rappaport E, Lajonchere CM, Munson J, Estes A, Korvatska O, Piven J, Sonnenblick LI, Alvarez Retuerto Al, Herman El, Dong $H$, Hutman T, Sigman M, Ozonoff S, Klin A, Owley T, Sweeney JA, Brune CW, Cantor RM, Bernier R, Gilbert JR, Cuccaro ML, McMahon WM, Miller J, State MW, Wassink TH, Coon H, Levy SE, Schultz RT, Nurnberger JI, Haines JL, Sutcliffe JS, Cook EH,
Minshew NJ, Buxbaum JD, Dawson G, Grant SF, Geschwind DH, Pericak-Vance MA, Schellenberg GD, Hakonarson H (2009) Common genetic variants on $5 \mathrm{p} 14.1$ associate with autism spectrum disorders. Nature 459:528-533

Willemsen MH, Fernandez BA, Bacino CA, Gerkes E, de Brouwer AP, Pfundt R, Sikkema-Raddatz B, Scherer SW, Marshall CR, Potocki L, van Bokhoven H, Kleefstra T (2010) Identification of ANKRD11 and ZNF778 as candidate genes for autism and variable cognitive impairment in the novel 16q24.3 microdeletion syndrome. Eur J Hum Genet 18:429-435

Williams ME, de Wit J, Ghosh A (2010) Molecular mechanisms of synaptic specificity in developing neural circuits. Neuron 68:9-18

Woo J, Kwon SK, Choi S, Kim S, Lee JR, Dunah AW, Sheng M, Kim E (2009) Trans-synaptic adhesion between NGL-3 and LAR regulates the formation of excitatory synapses. Nat Neurosci 12:428-437

Wyszynski M, Kim E, Dunah AW, Passafaro M, Valtschanoff JG, Serra-Pagès C, Streuli M, Weinberg RJ, Sheng M (2002) Interaction between GRIP and Liprin-a/SYD2 Is Required for AMPA Receptor Targeting. Neuron 34:39-52

$\mathrm{Xu} \mathrm{NJ}$, Henkemeyer M (2012) Ephrin reverse signaling in axon guidance and synaptogenesis. Semin Cell Dev Biol 23:58-64

Xu J, Litterst C, Georgakopoulos A, Zaganas I, Robakis NK (2009) Peptide EphB2/CTF2 generated by the gamma-secretase processing of EphB2 receptor promotes tyrosine phosphorylation and cell surface localization of $\mathrm{N}$-methyl-D-aspartate receptors. J Biol Chem 284:27220-27228

Yamada A, Irie K, Deguchi-Tawarada M, Ohtsuka T, Takai Y (2003) Nectin-dependent localization of synaptic scaffolding molecule (S-SCAM) at the puncta adherentia junctions formed between the mossy fiber terminals and the dendrites of pyramidal cells in the CA3 area of the mouse hippocampus. Genes Cells 8:985-994

Yamada M, Hashimoto T, Hayashi N, Higuchi M, Murakami A, Nakashima T, Maekawa S, Miyata S (2007) Synaptic adhesion molecule OBCAM., synaptogenesis and dynamic internalization. Brain Res 1165:5-14

Yan J, Noltner K, Feng J, Li W, Schroer R, Skinner C, Zeng W, Schwartz CE, Sommer SS (2008) Neurexin 1alpha structural variants associated with autism. Neurosci Lett 438:368-370

Yim YS, Kwon Y, Nam J, Yoon HI, Lee K, Kim DG, Kim E, Kim CH, Ko J (2013) Slitrks control excitatory and inhibitory synapse formation with $L A R$ receptor protein tyrosine phosphatases. Proc Natl Acad Sci USA 110:4057-4062

Zhang C, Milunsky JM, Newton S, Ko J, Zhao G, Maher TA, TagerFlusberg $\mathrm{H}$, Bolliger MF, Carter AS, Boucard AA, Powell CM, Südhof TC (2009) A neuroligin-4 missense mutation associated with autism impairs neuroligin-4 folding and endoplasmic reticulum export. J Neurosci 29:10843-10854

Zhao L, Ma QL, Calon F, Harris-White ME, Yang F, Lim GP, Morihara T, Ubeda OJ, Ambegaokar S, Hansen JE, Weisbart RH, Teter B, Frautschy SA, Cole GM (2006) Role of p21-activated kinase pathway defects in the cognitive deficits of Alzheimer disease. Nat Neurosci 9:234-242

Zhou L, Jones EV, Murai KK (2012) EphA signaling promotes actinbased dendritic spine remodeling through slingshot phosphatase. J Biol Chem 287:9346-9359 